\title{
Synthesis, stability and mechanistic studies of potent
}

\section{anticryptococcal hexapeptides}

\author{
Kitika Shenmar, ${ }^{a}$ Krishna K. Sharma, ${ }^{a}$ Nishima Wangoo, ${ }^{b}$ Indresh K. Maurya, ${ }^{c}$ Vinod \\ Kumar, ${ }^{\text {d }}$ Shabana I. Khan, ${ }^{\mathrm{e}}$ Melissa R. Jacob, ${ }^{\mathrm{e}}$ Kulbhushan Tikoo ${ }^{\mathrm{d}}$ and Rahul Jain ${ }^{\mathrm{a} *}$ \\ ${ }^{a}$ Department of Medicinal Chemistry, National Institute of Pharmaceutical Education \\ and Research, Sector 67, S. A. S. Nagar, Punjab, 160 062, India \\ ${ }^{b}$ Department of Applied Sciences, University Institute of Engineering and Technology \\ (U.I.E.T.), Panjab University, Sector-25, Chandigarh-160014, India \\ ${ }^{c}$ Department of Microbial Biotechnology, Panjab University, Sector-14, Chandigarh- \\ 160014, India \\ ${ }^{d}$ Department of Pharmacology and Toxicology, National Institute of Pharmaceutical \\ Education and Research, Sector 67, S. A. S. Nagar, Punjab, 160 062, India \\ ${ }^{e}$ National Center for Natural Products Research, School of Pharmacy, The University of \\ Mississippi, University, MS 38677, USA
}

\section{Address for correspondence:}

Dr. Rahul Jain

Department of Medicinal Chemistry

National Institute of Pharmaceutical Education and Research

Sector 67, S. A. S. Nagar, Punjab, 160 062, India

E-mail: rahuljain@ niper.ac.in

Tel.: 91-172-2292024; Fax: 91-172-2214692 


\begin{abstract}
The growing incidents of cryptococcosis in immuno-compromised patients have created a need for novel drug therapies capable of eradicating the disease. The peptide-based drug therapy offers many advantages over the traditional therapeutic agents, which has been exploited in the present study by synthesizing a series of hexapeptides that exhibits promising activity against a panel of Gram-negative and Gram-positive bacteria and various pathogenic fungal strains; the most exemplary activity was observed against Cryptococcus neoformans. The peptides 3, 24, 32 and 36 displayed potent anticryptococcal activity $\left(\mathrm{IC}_{50}=0.4-0.46 \mu \mathrm{g} / \mathrm{mL}, \mathrm{MIC}=0.63-1.25 \mu \mathrm{g} / \mathrm{mL}, \mathrm{MFC}=\right.$ $0.63-1.25 \mu \mathrm{g} / \mathrm{mL}$ ), and stability under proteolytic conditions. Besides this, several other peptides displayed promising inhibition of pathogenic bacteria. The prominent ones include peptides 18-20, and 26 that exhibited $\mathrm{IC}_{50}$ values ranged between $2.1-3.6$ $\mu \mathrm{g} / \mathrm{mL}$, MICs of $5-20 \mu \mathrm{g} / \mathrm{mL}$ and MBCs of $10-20 \mu \mathrm{g} / \mathrm{mL}$ against Staphylococcus aureus and methicillin-resistant $S$. aureus. The detailed mechanistic study on selected peptides demonstrated absolute selectivity towards the bacterial membranes and fungal cells by causing perturbations in the cell membranes, confirmed by the scanning electron microscopy and transmission electron microscopy studies.
\end{abstract}

Keywords: Anticryptococcal; Amphiphilic hexapeptides, Solid phase peptide synthesis; Proteolysis; Electron microscopy. 


\section{Introduction}

Immuno-compromised patients are the most susceptible targets for mycosis. Cryptococcosis, a fungal infection, whose etiological agents include, Cryptococcus neoformans and Cryptococcus gatii affects immuno-compromised and immunocompetent patients. The $C$. neoformans infections manifested in immuno-compromised patients, are the chief reason behind the deaths caused by fatal meningoencephalitis, observed in acquired immune deficiency syndrome (AIDS) patients $[1,2]$. Due to growing AIDS pandemic, the simultaneous spread of $C$. neoformans is also expanding creating a need to discover new drugs.

Antimicrobial peptides (AMPs) are part of innate immunity system of the organisms and have been isolated from almost all life forms including plants, animals, microbes and insects [3-9]. AMPs are usually dual cationic and hydrophobic in nature, with a tendency to fold into amphiphilic structures upon coming in close proximity of target membranes. Their unique mode of action involves non-specific membrane interactions leading to its disruption and leakage of the cell contents resulting in cell death [10]. The cell lysis is not peptide sequence dependent, instead physicochemical interactions (amphiphilicity and basicity), which forms the basis of molecular mechanisms are responsible for the targeting and killing of microbial cells [11]. Because of their natural origin, AMPs are predisposed to effectively distinguish between host and pathogen cells. The difference in membrane compositions of host and pathogen cells forms the basis of dissimilarity and results in the selective action of AMPs [12]. A large number of short-peptide based and non-peptide based compounds exhibiting promising antifungal activity, including activity against $C$. neoformans are reported [13-20]. 
The ability of human body to degrade peptides metabolically poses one of the biggest challenges in the development of peptide-based antibiotics [21]. Other factors that play considerable role are the high cost of production due to long amino acid sequences of AMPs, immunogenic properties, simultaneous action of peptides on multiple targets at once, leading to side effects $[22,23]$. Hence, due to all these reasons, traditionally peptide-based drugs have not been explored [24]. The use of unnatural amino acids, amide backbone modification, tethering the peptide core using various linkers, conjugating lipophilic acids, increasing the bulk of the peptide by hydrophobic tagging using tryptophan, and truncation of larger peptides or proteins while retaining the essential bioactive core sequences are some of the techniques employed for the generation of peptide-based therapeutics that retains and enhances the efficacy of native peptides [25-29]. A number of hexapeptides are known to exhibit anti-candicidal, antistaphylococcal and anti-Escherichia coli activity with MICs in micro molar range [30, 31]. The growth hormone (GH, somatotropin) regulates body composition in adults and optimal statural growth in children [32]. Ghrelin is the endogenous ligand for the GH secretagogue receptor (GHSR) and stimulates the anterior pituitary gland to release GH [33-38]. Recently, ghrelin has been observed to possesses bactericidal activity against Gram-ve E. coli and Pseudomonas aeruginosa [39].

\section{Results and discussion}

Several truncated analogues of 191 amino acids containing GH have been synthesized. A study resulted in the identification of a synthetic congener called GHRP-6 (His-D-TrpAla-Trp-D-Phe-Lys- $\mathrm{NH}_{2}$ ) [40]. This peptide served as the lead for a number of optimization studies resulting in peptides that possessed a variety of pharmacological 
activities, ranging from wound healing to antifungal [41, 42]. One such identified peptide, His-D-Trp-D-Phe-Phe-D-Phe-Lys- $\mathrm{NH}_{2}$ exhibited antifungal activity against five pathogenic fungi in the range of $6.2-100 \mu \mathrm{g} / \mathrm{mL}$. Further structural optimization by bioscreening of synthetic combinatorial libraries resulted in the identification of another antifungal peptide Arg-D-Trp-D-Phe-Ile-D-Phe-His- $\mathrm{NH}_{2}$ that exhibit $\mathrm{IC}_{50}$ value of $6.8 \mu \mathrm{M}$ against Candida albicans [43, 44]. A detailed investigation by our group, of the above mentioned peptide resulted in several analogues with far superior antimicrobial activity [45]. In the present study, out of the many bioactive peptides, Orn-D-Trp-Cha-Ile-D-PheHis(1-Bzl)-NH $\mathrm{NH}_{2}$ (1) and Orn-D-Trp-D-Phe-Phe(4-Me)-D-Phe-His(1-Bzl)-NH $\mathrm{NH}_{2}$ (2) were chosen for further in-depth structural optimization (Fig. 1). The peptides 1-2 displayed a cross-sectional activity profile with $\mathrm{IC}_{50} \mathrm{~s}$ in the range of $0.07-18.9 \mu \mathrm{g} / \mathrm{mL}$ and MICs in the range of $1-100 \mu \mathrm{g} / \mathrm{mL}$ against methicillin-resistant Staphylococcus aureus (MRSA), methicillin-resistant S. epidermis (MRSE), E. coli and C. albicans. In this study, it was assumed that independent replacement to the hydrophilic or hydrophobic core of peptides 1-2 could possibly result in enhancement of biological activity along with selectivity for bacteria or fungi. In peptide 1, we retained the terminus hydrophilic amino acids while hydrophobic core was replaced with physico-chemically analogous amino acids. In peptide 2 , the hydrophobic core was kept intact, while the terminus hydrophilic amino acids were independently replaced with physico-chemically analogous amino acids (Fig. 1). The overall net charge, facial amphilicity, and optimal hydrophobic bulk were considered as key factors in selecting replacement amino acids [46-48].

\section{Modifications at positions 2, 4 and 5 of peptide 1}


To study the effect of varying the hydrophobicity on the bioactivity of peptide Orn-DTrp-Cha-Ile-D-Phe-His(1-Bzl)- $\mathrm{NH}_{2}$ (1), constituent amino acids contributing to the hydrophobic core were systematically and independently replaced. First we replaced DTrp at the position 2 of peptide 1 with bulky proteogenic and non-proteogenic amino acids, resulting in the synthesis of peptides 3-12. The peptides were synthesized using Fmoc-based solid phase peptide synthesis protocol exemplified by synthesis of peptide $\mathbf{3}$ (Scheme 1). Isoleucine, a moderately hydrophobic amino acid present at the position 4 of peptide 1 was replaced next with various counterpart amino acids. The chosen replacement amino acids vary from moderately hydrophobic to highly hydrophobic, leading to peptides 13-21. The amino acid phenylalanine (D-Phe) at provides bulk and considered as a contributing factor in the maintenance of the ideal bulk-to-charge ratio required for exerting antimicrobial activity. The replacement of D-Phe at the position 5 of peptide 1 with non-proteiogenic amino acids with enhanced bulk and hydrophobic character resulted in the synthesis of peptides $\mathbf{2 2 - 2 5}$. The other hydrophobic amino acid cyclohexylalainine (Cha) considered critical for activity was not replaced.

\section{Modifications at positions 1 and 6 of peptide 2}

As discussed above, in the case of antimicrobial peptides a fine balance between amphilicity and hydrophobicity enables them to exert activity. The hydrophobic core of peptide Orn-D-Trp-D-Phe-Phe(4-Me)-D-Phe-His(1-Bzl)-NH $\mathrm{NH}_{2}$ (2) is already composed of hydrophobic unnatural amino acids, and thus we replaced both terminus hydrophilic amino acids [Orn and His(1-Bzl)]. The replacement of ornithine (Orn) at the N-terminus resulted in the synthesis of five peptides 26-30. The replacement amino acids were aliphatic proteiogenic and non-proteiogenic amino acids [L-Arg, D-Arg, Lys and 2,4- 
diaminobutyric acid (Dab)], besides aromatic 4-aminophenylalanine [Phe(4-NH$)]$. CTerminus in peptide 2 contains amphiphilic 1-benzylhistidine [His(1-Bzl)] residue that provide charge via imidazole ring and hydrophobicity via benzyl ring. The replacement amino acids used were a combination of both natural and unnatural amino acids [His, DHis, D-Lys, D-Arg, Orn, D-Orn, Dab) and Phe $\left(4-\mathrm{NH}_{2}\right)$ ], chosen in a way that they would contribute in increasing the overall cationic charge of final peptides 31-38.

\subsection{Antimicrobial activity and cytotoxicity evaluation}

Various pathogenic bacteria such as S. aureus, E. coli, P. aeruginosa, Mycobacterium intracellulare, and MRSA were used as targets for in vitro testing of the peptides. The susceptibility of the fungal strains C. neoformans, C. albicans, C. glabrata, C. krusei and Aspergillus fumigatus were also evaluated for the synthesized peptides and results are summarized in Tables 1-2.

In general, peptides exhibited promising activity against fungal strains (Table 1). Peptides 13, 17, 18, 19, 20, 21, 24, and 25-26 produced $\mathrm{IC}_{50}$ values ranged between $6.05-19.6$ $\mu \mathrm{g} / \mathrm{mL}$, while minimum inhibitory concentration (MIC) and minimum fungicidal concentration (MFC) values between $10-20 \mu \mathrm{g} / \mathrm{mL}$ were displayed against $C$. albicans. Against $C$. glabrata, peptides 18, 19, 22, and 24-25 displayed $\mathrm{IC}_{50}$ s between $7.56-17.9$ $\mu \mathrm{g} / \mathrm{mL}$, while MICs and MFCs between $10-20 \mu \mathrm{g} / \mathrm{mL}$ were produced. A large number of peptides showed promising inhibition of $C$. krusei. The most promising peptide 25 [Orn-D-Trp-Cha-Ile-Ala(9-anth)-His(1-Bzl)-NH $\mathrm{NH}_{2}$ exhibited $\mathrm{IC}_{50}$ of $3.81 \mu \mathrm{g} / \mathrm{mL}, \mathrm{MIC}$ of $5 \mu \mathrm{g} / \mathrm{mL}$ and MFC value of $10 \mu \mathrm{g} / \mathrm{mL}$. The remaining active peptides $3, \mathbf{1 0}, \mathbf{1 3 - 1 6}, \mathbf{2 4}$, 26-28, 30, 32-33, and 35-38 produced $\mathrm{IC}_{50}$ s between $5.16-19.98 \mu \mathrm{g} / \mathrm{mL}$. The same set of peptides also exhibited MIC and MFC values ranged in $10-20 \mu \mathrm{g} / \mathrm{mL}$ against $C$. 
krusei. Fungal strain A. fumigatus proved to be least susceptible to peptides of the series; the exceptions being peptides 18-20 that produced $\mathrm{IC}_{50} \mathrm{~s}$ ranged between $6.56-19.9$ $\mu \mathrm{g} / \mathrm{mL}$ and MIC and MFC values between $10-20 \mu \mathrm{g} / \mathrm{mL}$. In general, peptides exhibited highly potent activity $\left(\mathrm{IC}_{50}=0.4-4.73 \mu \mathrm{g} / \mathrm{mL}, \mathrm{MIC}=0.63-5.00 \mu \mathrm{g} / \mathrm{mL}, \mathrm{MFC}=0.63-\right.$ $5.00 \mu \mathrm{g} / \mathrm{mL}$ ) against $C$. neoformans. Some of the significantly potent peptides of the series are 3 (Orn-Trp-Cha-Ile-D-Phe-His(1-Bzl)-NH $\mathrm{NH}_{2}, \mathrm{IC}_{50}=0.42 \mu \mathrm{g} / \mathrm{mL}, \mathrm{MIC}=\mathrm{MFC}=$ $0.63 \mu \mathrm{g} / \mathrm{mL}), 24$ (Orn-D-Trp-Cha-Ile-Cha-His(1-Bzl)-NH $\mathrm{NH}_{2}, \mathrm{IC}_{50}=0.46 \mu \mathrm{g} / \mathrm{mL}, \mathrm{MIC}=$ MFC $=1.25 \mu \mathrm{g} / \mathrm{mL}$ ), 32 (Orn-D-Trp-D-Phe-Phe(4-Me)-D-Phe-Orn- $\mathrm{NH}_{2}, \quad \mathrm{IC}_{50}=0.46$ $\mu \mathrm{g} / \mathrm{mL}$, MIC $=$ MFC $=00.63 \mu \mathrm{g} / \mathrm{mL}$ ) and 36 (Orn-D-Trp-D-Phe-Phe(4-Me)-D-Phe-DLys- $\mathrm{NH}_{2}, \quad \mathrm{IC}_{50}=0.40 \mu \mathrm{g} / \mathrm{mL}$, MIC $\left.=\mathrm{MFC}=0.63 \mu \mathrm{g} / \mathrm{mL}\right)$. The inhibitory values exhibited by these and a large number of other peptides of the series were superior compared to standard drug amphotericin $\mathrm{B}\left(\mathrm{IC}_{50}=0.69 \mu \mathrm{g} / \mathrm{mL}, \mathrm{MIC}=\mathrm{MFC}=1.25\right.$ $\mu \mathrm{g} / \mathrm{mL}$ ). The potent anticryptococcal activity was noted when D-Trp at position 2 was replaced with L-Trp residue in peptide $\mathbf{1}$, resulting in peptide $\mathbf{3}$. Similarly, potent peptide 24 was obtained by replacement of D-Phe ${ }^{4}$ with unnatural residue Cha in peptide 1 . On the other hand, potent peptides $\mathbf{3 2}$ and $\mathbf{3 6}$ were synthesized by replacing His(1-Bzl $)^{6}$ with unnatural residues ornithine (Orn) and D-lysine (D-Lys), respectively. It may be noted that potent peptides $\mathbf{3 2}$ and $\mathbf{3 6}$ are composed of only unnatural amino acids, whereas peptides 3 and 24 contains four and five unnatural amino acids in their respective composition (Table 1).

The peptides 18 and 26 exhibited promising antibacterial activity ( $\mathrm{IC}_{50}=3.2 \mu \mathrm{g} / \mathrm{mL}$, MIC $=10-20 \mu \mathrm{g} / \mathrm{mL}, \mathrm{MBC}=20 \mu \mathrm{g} / \mathrm{mL})$ upon evaluation against pathogenic MRSA strain. The remaining active peptides of the series exhibited $\mathrm{IC}_{50}$ values ranged between $5.8-$ 
$18.6 \mu \mathrm{g} / \mathrm{mL}$. In the case of $S$. aureus, peptides 25 produced very promising activity ( $\mathrm{IC}_{50}$ $=1.61 \mu \mathrm{g} / \mathrm{mL}, \mathrm{MIC}=5 \mu \mathrm{g} / \mathrm{mL}, \mathrm{MBC}=10 \mu \mathrm{g} / \mathrm{mL}$ ), while peptides 18, 19, 20, 26 and $\mathbf{3 0}$ exhibited $\mathrm{IC}_{50}$ values of $2.4,2.63,3.6,2.1$ and $6.0 \mu \mathrm{g} / \mathrm{mL}$, respectively. The peptides were noted to show less potency against $E$. coli. The peptide $\mathbf{3 7}$ produced $\mathrm{IC}_{50}$ value of $4.86 \mu \mathrm{g} / \mathrm{mL}$ (E. coli). In general, peptides did not show promising inhibition of $P$. aeruginosa and $M$. intracellulare; the exception being peptide 26 that exhibited $\mathrm{IC}_{50}$ value of $6.5 \mu \mathrm{g} / \mathrm{mL}$ and $\mathrm{MIC}$ and $\mathrm{MBC}$ value of $10 \mu \mathrm{g} / \mathrm{mL}$ against $M$. intracellulare (Table 2).

The in vitro cytotoxic effects of the synthesized peptides was determined against noncancerous VERO cells obtained from ATCC, American Type Culture Collection. None of the tested peptides were cytotoxic up to the highest concentration of $10 \mu \mathrm{g} / \mathrm{mL}$ thereby providing a selective index between $>21-25$ for the potent peptides $(\mathbf{3}, \mathbf{2 4}, \mathbf{3 2}$ and 36) (Table 1).

\subsection{Tryptophan quenching study}

Liposomes are microscopic phospholipid bubbles with at least a single lipid-layered membrane structure [49]. When only a single amphiphilic lipid layer is present, liposomes are called small unilamellar vesicles (SUVs). Based on their phospholipid composition, SUVs can be altered to represent either bacterial membrane-mimics or mammalian membrane-mimics. The bacterial cell membranes are composed of more negatively charged lipopolysaccharides and acids, whereas the mammalian cell membranes are zwitterionic in nature. In order to ascertain that synthesized peptides have the ability and specificity to target only bacterial cells over the mammalian cells and cause selective membrane disruption, we used synthetic bacterial and mammalian 
membrane mimics for testing five selected peptides $(\mathbf{3}, \mathbf{2 4}, \mathbf{3 2}, \mathbf{3 4}$ and 36). Peptides $\mathbf{3}, \mathbf{2 4}$, 32, and 36 constitute a group that displayed highest anticryptococcal activity while peptide $\mathbf{3 4}$ was the least active of the set. The peptides were read for their fluorimetric emission spectrum and the readings plotted in the form of Stern-Volmer plots (Fig. 2).

The plots depict the difference in the slopes of graphs upon the differential interactions of the peptides in the presence/absence of SUVs. In the case of control (Tris-HCl) graph, the fluorescence of peptides decreases in a concentration dependent manner by addition of acrylamide. But as there were no SUVs in this solution, hence, Trp residue was freely available for quenching by acrylamide resulting in a higher slope of the graph as compared to SUVs containing solutions. On the other hand, the EYPC:EYPG containing negatively charged bacterial membrane mimicking SUVs electrostatically attracted active peptides, resulting in successful burial of peptides within the membrane. As a result, the Trp residue was unavailable for quenching by acrylamide, and the Stern-Volmer plot shows equal Trp-quenching as the slope of the representative graph. In the case of EYPC:cholesterol SUVs, the peptides do not preferentially bind to zwitterionic membrane mimicking SUVs, and thus, the Trp residue is not buried in the SUVs membrane and is available for quenching by acrylamide. The slope of this graph is higher than that of bacterial membrane mimicking SUVs and peptide interactions and lower than that of the control.

\subsection{Trypsin digestion study}

To determine the proteolytic stability, a trypsin digestion study was performed on the hexapeptides 3, 32 and 36. As seen from the HPLC chromatogram, peptide remains stable after $24 \mathrm{~h}$ of trypsin treatment. This shows that all three peptides retained its 
structural integrity during trypsin digestion, and was not susceptible to proteolytic action of the enzyme (Fig. 3).

\subsection{Scanning electron microscopic (SEM) study}

In order to gain further insights into the mechanism of action of the designed peptides, two of the most active peptides $\mathbf{3}$ and $\mathbf{3 6}$ along with the least active peptide $\mathbf{3 4}$ of the series were treated with real $C$. neoformans fungal biofilms, and analyzed using scanning electron microscopy (SEM). The SEM imaging of the blank sample revealed smooth surfaced fungal cells of the fungal biofilm (Fig 4a). After treatment with the most active peptide $\mathbf{3}$ and 36, the cells appeared to have been lysed, in the process, created holes in the fungal biofilm (Fig 4b-c). However, in the case of peptide 34, the cells appear to be corrugated and perturbations led to the killing of the fungal cells (Fig. 4d).

\subsection{Transmission electron microscopy (TEM) study on artificial membranes}

Trp-quenching and SEM studies regarding the mechanism of action of the peptides had shed light on their selectivity towards the bacterial cells and the damage caused to the $C$. neoformans fungal biofilms (seen as surface deformities). To gain insights with respect to the internal damage caused to the bacterial cells by the peptides, we undertook transmission electron microscopic (TEM) study. We first analyzed the effect of peptide treatment on the bacterial membrane-mimicking and mammalian-mimicking SUVs. The

most active peptide 36 was chosen for the study. The image of bacterial membranemimicking liposomes taken in the absence of $\mathbf{3 6}$ show smooth and spherical morphology with an average diameter of 20-100 nm (Fig 5a). On the other hand, images of peptide 36 treated liposomes showed lysed and disfigured bacterial membrane-mimicking liposomes (Fig 5b). In the case of mammalian membrane-mimicking liposomes, peptide $\mathbf{3 6}$ has 
virtually left the liposomes intact proving its selectivity towards the bacterial cells (Figs. 5c-d).

\subsection{Transmission electron microscopy (TEM) study on C. neoformans biofilms}

After gaining information about the interactions of the active peptide $\mathbf{3 6}$ with the membrane mimicking SUVs, we finally studied the interactions of peptides $\mathbf{3}, \mathbf{3 4}$ and 36 with $C$. neoformans biofilm. The images obtained in the study describe the events leading to death of the fungal cells. The ultrastructure of the untreated $C$. neoformans cells (Fig. 6a) depicts cells containing a healthy granular cell membrane (as shown by the arrow). Upon treatment of $C$. neoformans biofilm with $\mathbf{3}$, it was observed that the cell wall loses its granularity leading to leakage of cytoplasm (Fig. 6b). In the case of peptide 34, the biofilm show the loss of cell wall as no granular outer layer can be distinguished (Fig. 6c). The TEM image for peptide $\mathbf{3 6}$ show the abnormal subcellular morphology with the formation of pits as depicted by the arrows in Fig. 6d. These results demonstrate that peptides exhibit the potent antifungal bioactivity by disruption in the cell wall of the pathogenic fungi.

\section{Conclusions}

In this study, thirty-six peptides were synthesized by modifying hydrophobic core and hydrophilic C- and N-terminus of peptides 1-2. All synthesized peptides were subjected to in vitro antimicrobial activity evaluation against a panel of pathogenic bacteria and fungi. Some of the synthesized peptides displayed remarkably high activity against fungi C. neoformans. A number of peptides also exhibited high potency against pathogenic bacteria. The study revealed the identity of anticryptococcal hexapeptides having potent efficacy against $C$. neoformans as compared to the standard drug amphotericin B. The 
synthesized peptides show selectivity towards the bacterial membranes over their mammalian counterparts as proven by the tryptophan fluorescence quenching study. The trypsin digestion study confirms the stability of peptide $\mathbf{3}$ and $\mathbf{3 6}$ under the proteolytic conditions, thereby providing evidence of its suitability as promising drug candidate. The SEM study provides insights into the damage caused by the active peptides $\mathbf{3}$ and $\mathbf{3 6}$ to fungal biofilm. The TEM study on artificial membranes provided evidence for the damage caused exclusively to the bacterial membrane mimicking SUVs by peptide 3 . The TEM study using fungal biofilm of $C$. neoformans showed the effect of the peptide treatment at the cellular level with the images confirming the effect on the fungal cell wall. In conclusion, the promising peptides composed of mostly non-proteiogenic amino acids are a new class of compounds that have potential utility in the treatment of pathogenic opportunistic infections caused by bacteria and fungi.

\section{Experimental}

\subsection{Synthesis}

All chemicals were purchased from Sigma-Aldrich, Missouri, U.S.A. and Chem-Impex International, Illinois, U.S.A. and used without any further purification, unless specified. Peptide synthesis was performed on Aapptec fully automated peptide synthesizer using Fmoc synthesis protocol. The high-resolution mass spectra were recorded on a MAXISBruker spectrometer using ESI-TOF method. The peptides were analyzed on a Shimadzu SPD-M20A analytical HPLC system using a supelcosil ${ }^{\mathrm{TM}}$ LC-8, $5 \mu \mathrm{m}(25 \mathrm{~cm} \times 4.6 \mathrm{~mm}$ ID) column. The peptides were purified on the Shimadzu HPLC preparative system using a Luna $10 \mu \mathrm{M}$ C18 (2) (250 mm x $21.2 \mathrm{~mm}, 10 \mu \mathrm{m})$ column.

\subsubsection{General procedure for solid phase synthesis of peptides}


In a reaction vessel, Fmoc-protected Rink amide MBHA resin was first swelled in DMF for fifteen min. A solution of $20 \%$ piperidine in DMF was added and mixture shaken mechanically for 15 min resulting in the removal of Fmoc group. The required Fmoc protected amino acids and coupling reagent 2-(1H-benzotriazole-1-yl)-1,1,3,3tetramethyluronium tetrafluoroborate (TBTU) were placed in amino acid vessels sequentially. DMF was added to the amino acid vessel, which was subsequently added (by positive pressure of $\mathrm{N}_{2}$ ) to the reaction vessel containing the resin, followed by addition of $N, N$-diisppropylethylamine (DIEA). After $3 \mathrm{~h}$ of mechanical shaking at ambient temperature, the solvent was drained and the resin washed with DMF $(3 \times 5$ min $)$ followed by methanol $(2 \times 5 \mathrm{~mL})$. The cycles of deprotection and coupling were repeated till the desired peptide chain length was obtained. The resin-bound peptide was transferred to a round bottom flask, and simultaneous removal of resin and protective groups was achieved by using a cocktail combination of TFA:triisopropylsilane (TIPS): $\mathrm{H}_{2} \mathrm{O}$ [95:2.5:2.5] for $3 \mathrm{~h}$. The crude peptide was filtered and purified on preparative HPLC system, and analyzed using solvent system of $\mathrm{CH}_{3} \mathrm{CN}-\mathrm{H}_{2} \mathrm{O}-0.1 \%$ $\mathrm{CF}_{3} \mathrm{COOH}$ in the gradient system: 30 min gradient, 30-100\% $\mathrm{CH}_{3} \mathrm{CN}-\mathrm{H}_{2} \mathrm{O}-0.1 \%$ $\mathrm{CF}_{3} \mathrm{COOH}$ at $215 \mathrm{~nm}$.

\subsection{Antimicrobial activity evaluation}

The antibacterial activities of synthesized peptides were evaluated against Staphylococcus aureus ATCC 29213, methicillin-resistant S. aureus ATCC 33591 (MRSA), Mycobacterium intracellulare ATCC 23068, Escherichia coli ATCC 35218 and Pseudomonas aeruginosa ATCC 27853. Susceptibility of S. aureus, MRSA, E. coli and $P$. aeruginosa to test compounds was determined using CLSI methods $[50,51]$. 
Susceptibility of $M$. intracellulare was determined using the modified Alamar Blue procedure of Franzblau et al. [52]. The antifungal activities of the target compounds against Cryptococcus neoformans ATCC 90113, C. albicans ATCC 90028, C. glabrata ATCC 90030, C. krusei ATCC 6258, and A. fumigatus ATCC 90906 were determined according to modified CLSI methods [53].

Test Procedure: Samples are serially-diluted in $20 \% \mathrm{DMSO} / \mathrm{saline}$ and transferred in duplicate to 96 well flat bottom microplates. Inocula are prepared by correcting the $\mathrm{OD}_{630}$ of microbe suspensions in incubation broth [RPMI 1640/2\% dextrose/0.03\% glutamine/MOPS @ pH 6.0 (Cellgro) for C. albicans, Sabouraud Dextrose for $C$. neoformans, cation-adjusted Mueller-Hinton (Difco) @ pH 7.3 for MRS, 5\% Alamar Blue $^{\mathrm{TM}}$ (BioSource International, Camarillo, CA) in Middlebrook 7H9 broth with OADC enrichment, $\mathrm{pH}=7.3$ for $M$. intracellulare, and 5\% Alamar Blue $\mathrm{TM} / \mathrm{RPMI} 1640$ broth ( $2 \%$ dextrose, $0.03 \%$ glutamine, buffered with $0.165 \mathrm{M}$ MOPS at $\mathrm{pH} 7.3$ ) for A. fumigatus to afford final target inocula of: C. albicans: $1.0 \times 10^{4}$, C. neoformans: $1.0 \times 10^{5}, M$. intracellulare: $2.0 \times 10^{6}$, MRS, C. glabrata, C. krusei: $5.0 \times 10^{5} \mathrm{CFU} / \mathrm{mL}$, and A. fumigatus: $3.0 \times 10^{4} \mathrm{CFU} / \mathrm{mL}$. Drug controls [Ciprofloxacin (ICN Biomedicals, Ohio) for bacteria and Amphotericin B (ICN Biomedicals, Ohio) for fungi] are included in each assay. All organisms are read at either $630 \mathrm{~nm}$ using the EL-340 Biokinetics Reader (BioTek Instruments, Vermont) or 544ex/590em, (M. intracellulare, A. fumigatus) using the Polarstar Galaxy Plate Reader (BMG LabTechnologies, Germany) prior to and after incubation: C. albicans, MRS, C. glabrata and C. krusei at $37^{\circ} \mathrm{C}$ for $18-24 \mathrm{~h}, C$. neoformans and A. fumigatus at $30{ }^{\circ} \mathrm{C}$ for $68-72 \mathrm{~h}$, and M. intracellulare at $37^{\circ} \mathrm{C}$ and $10 \% \mathrm{CO}_{2}$ for $68-72 \mathrm{~h}$. The MIC is defined as the lowest test concentration that allows 
no detectable growth (for $M$. intracellulare and A. fumigatus, no color change from blue to pink). Minimum fungicidal or bactericidal concentrations are determined by removing

$5 \square \mathrm{L}$ from each clear (or blue) well, transferring to agar and incubating as previously mentioned. The MFC/MBC is defined as the lowest test concentration that kills the organism (allows no growth on agar).

\subsection{Cytotoxicity evaluation}

The noncancerous VERO cells obtained from ATCC, American Type Culture Collection, were used to test for the in vitro cytotoxic effects of the synthesized peptides by neutral red assay [54].

Test procedure: The assay was performed in 96-well tissue culture-treated microplates and peptides were tested up to a highest concentration of $10.00 \mu \mathrm{g} / \mathrm{mL}$. The cells ( 25000 cells/well) were seeded to the walls of the wells and incubated for $24 \mathrm{~h}$. After sample addition, the plates were again incubated for an additional $48 \mathrm{~h}$. The number of viable cells was counted using a modified procedure for the neutral red assay. The $\mathrm{CC}_{50}$ were computed from the logarithmic graphs of growth inhibition versus concentration of the test peptide. The controls used in this assay were doxorubicin as the positive control and DMSO as the negative or vehicular control.

\subsection{Tryptophan quenching assay}

The egg yolk L- $\alpha$-phosphatidylcholine (EYPC), egg yolk L- $\alpha$-phosphatidyl-D,L-glycerol (EYPG), acyrlamide and cholesterol were purchased from Sigma Chemical Company, St. Louis, USA and used without any further purification. All other reagents were analytical grade. The buffers were prepared in double glass-distilled water. 
The SUVs were made comprising of lipid mixture EYPC, EYPG and/or cholesterol. The SUVs representative of bacterial $($ EYPC:EYPG $=7: 3)$ and mammalian cell membranes $($ EYPC:cholesterol $=10: 1)$ were prepared by dissolving the dry lipids in chloroform and then air dying. The dry lipids were re-suspended in Tris-HCl buffer ( $\mathrm{pH}$ 7.4) using vortex mixing. The dispersed lipids were sonicated for 10-15 $\mathrm{min}$ in an ice-water mixture, till the solution became transparent. The SUVs were incubated with selected peptides $\mathbf{3}, \mathbf{2 4}$, 32, 34 and 36. The concentration of the peptides taken was $0.1 \mu \mathrm{M}$. To investigate the relative extent of peptide burial in the model membranes, a fluorescence quenching experiment was performed using the Cary Eclipse spectrofluorometer at $25{ }^{\circ} \mathrm{C}$ and 300 $\mu \mathrm{L}$ quartz cuvette having $1 \mathrm{~cm}$ path length and a magnetically stirred, thermostated cuvette compartment using excitation wavelength of $295 \mathrm{~nm}$. The bandwidth of $5 \mathrm{~nm}$ was used for both excitation and emission. To reduce the absorbance by acrylamide, the excitation of Trp at $295 \mathrm{~nm}$, instead at $280 \mathrm{~nm}$ was used. The aliquots of $4.0 \mathrm{M}$ solution of the acrylamide were added to the peptide in the absence or presence of liposomes at a peptide-lipid molar ratio of 1:200. The acrylamide concentration in the cuvette varied from 0 to $0.20 \mathrm{M}$. The scan speed was $500 \mathrm{~nm} / \mathrm{min}$ with the emission intensities scanned from $300-550 \mathrm{~nm}$. An average of three scans per reading were taken after 5 min of equilibration before recording. The effect of acrylamide on the fluorescence of each peptide was analyzed with a Stern-Volmer equation:

$$
\mathrm{F}_{0} / \mathrm{F}=1+\mathrm{KSV}[\mathrm{Q}]
$$

Where, $\mathrm{F}_{0}$ and $\mathrm{F}$ represent the fluorescence intensities in the absence and the presence of acrylamide, respectively, KSV is the Stern-Volmer quenching constant, and [Q] is the concentration of acrylamide. 


\subsection{Scanning electron microscopy (SEM) and transmission electron microscopy (TEM) studies}

SEM sample preparation: The samples were prepared by first culturing $C$. neoformans in overnight growth cultures. The following day, cell suspensions were prepared using RPMI-1640 medium ( $\mathrm{pH}$ 7.4). This was followed by adding $\mathbf{3}, \mathbf{3 4}$ and $\mathbf{3 6}$ (at their MIC concentrations) to fungal cells $(\sim 1 \times 106 \mathrm{CFU} / \mathrm{mL})$ and incubating at $30{ }^{\circ} \mathrm{C}$. Upon treatment, the samples were fixed in glutaraldehyde followed by repetitive rinsing with 0.1 M sodium cacodylate and $0.22 \mathrm{M}$ sucrose solution. Poly-L-lysine hydrobromide was used as the coverslip coating material and the agar films were allowed to settle on the surface. The post-fixation process involved treatment with $2 \%$ osmium tetraoxide buffered to $\mathrm{pH} 7.4$ with $0.05 \mathrm{M}$ veronal acetate at $4{ }^{\circ} \mathrm{C}$ for $1 \mathrm{~h}$. The dehydration process involved a gradual gradient rinsing cycle with progressive ethanol-acetone mixture till the final rinse cycle reached $100 \%$ acetone. The sample coverslips were attached to the SEM holder and dried with $\mathrm{CO}_{2}$ till the critical point. The sample preparation's last step involved sputter coating with gold. The samples were analyzed using SEM (Zeiss EV040) $[55,56]$.

TEM study using artificial membranes (sample preparation): The appearance of the peptide 36 was monitored by depositing, on to a carbon coated copper grid, a drop of peptide solution $(0.5 \mu \mathrm{g} / \mathrm{mL})$, and negatively staining the sample with $2 \%(\mathrm{w} / \mathrm{v})$ phosphotungstic acid solution. The interactions were examined using TEM and multiple images were taken for each sample.

TEM study using actual fungal biofilms (sample preparation): The samples were prepared by incubating the fungal biofilm with the peptides $\mathbf{3}, \mathbf{3 4}$ and $\mathbf{3 6}$ at their 
respective MIC concentrations for $1 \mathrm{~h}$. Usually the samples are negatively stained using $1-2 \%$ of phosphotungstic acid, ammonium molybdate or uranyl acetate. The heavy metal staining allows for a better high contrast, which increases the 2D crystal lattices structural clarity under the electron microscope. Ultra-thin section cutting was done with an ultramicrotome (Ultramicotome Lecia EM UC6). The samples are then spotted on carbon coated copper grids and negatively stained. The transmission electron microscopy was performed on a Hitachi H-7500 microscope at an accelerating voltage of $200 \mathrm{kV}$. The carbon coated 400 mesh copper grids and the negative stain uranyl acetate was both obtained from the Agar Scientific, USA.

\subsection{Trypsin digestion study}

To study the stability of the peptides $\mathbf{3}, \mathbf{3 2}$ and $\mathbf{3 6}$ for tryptic degradation, peptide along with trypsin were taken in a molar ratio of 0.5:100 (peptide:trypsin) in a solution containing $0.1 \mathrm{M}$ ammonium bicarbonate $\left(\mathrm{NH}_{4} \mathrm{HCO}_{3}\right)$ and $0.1 \mathrm{mM}$ calcium chloride $\left(\mathrm{CaCl}_{2}\right)$ at $\mathrm{pH} 8.3$. The solution was incubated in a rotary shaker incubator $\left(37^{\circ} \mathrm{C}, 200\right.$ $\mathrm{rpm}, 24 \mathrm{~h}$ ). Aliquots of the solution were taken at time intervals of $0,2,4,8,12,18$ and $24 \mathrm{~h}$. Aliquots were analyzed on a Shimadzu SPD-M20A analytical HPLC system using a Supelcosil TM LC-8, $5 \mu \mathrm{m}\left(25 \mathrm{~cm} \times 4.6 \mathrm{~mm}\right.$ ID) column using $\mathrm{CH}_{3} \mathrm{CN}\left(0.1 \%\right.$ TFA): $\mathrm{H}_{2} \mathrm{O}$ ( $0.1 \%$ TFA) linear gradient system of 30-100\% in 30 min with a flow rate of $1 \mathrm{~mL} / \mathrm{min}$.

\section{Acknowledgements}

Kitika Shenmar thanks National Institute of Pharmaceutical Education and Research (NIPER) to Kitika Shenmar for providing senior research fellowship. Ms Marsh Wright and Mr John Trott are acknowledged for excellent technical support in biological testing at NCNPR. Antimicrobial testing was supported by the NIH, NIAID, Division of AIDS, 
Grant No. AI 27094 (antifungal) and the USDA Agricultural Research Service Specific Cooperative Agreement No. 58-6408-1-603 (antibacterial).

\section{References}

[1] K.J. Kwon-Chung, J.A. Fraser, T.L. Doering, Z. Wang, G. Janbon, A. Idnurm, Y.S. Bahn, Cryptococcus neoformans and Cryptococcus gattii, the etiologic agents of cryptococcosis, Cold Spring Harb Perspect Med. 4 (2014) a019760.

[2] C. Coelho, A. Casadevall, Cryptococcal therapies and drug targets: the old, the new and the promising, Cell Microbiol. 18 (2016) 792-799.

[3] W.F. Broekaert, B.P. Cammue, M.F. De Bolle, K. Thevissen, G.W. De Samblanx, R.W. Osborn, K. Nielson, Antimicrobial peptides from plants. Crit. Rev. Plant Sci. 16 (1997) 297-323.

[4] W.F. Broekaert, F. Terras, B. Cammue, R.W. Osborn, Plant defensins: novel antimicrobial peptides as components of the host defense system. Plant Physiol. 108 (1995) 1353.

[5] T. Ganz, Defensins: antimicrobial peptides of innate immunity. Nat. Rev. Immunol. 3 (2003) 710-720.

[6] T. Ganz, R.I. Lehrer, Antimicrobial peptides of vertebrates. Curr. Opin. Immunol. 10 (1998) 41-44.

[7] I.F. Nes, H. Holo, Class II antimicrobial peptides from lactic acid bacteria. Pept. Sci. 55 (2000) 50-61.

[8] P. Bulet, C. Hetru, J.-L. Dimarcq, D. Hoffmann, Antimicrobial peptides in insects; structure and function. Dev. Comp. Immunol. 23 (1999) 329-344. 
[9] P. Bulet, R. Stocklin, Insect antimicrobial peptides: structures, properties and gene regulation. Protein Pept. Lett. 12 (2005) 3-11.

[10] A. Mor, Peptide-based antibiotics: A potential answer to raging antimicrobial resistance. Drug Dev. Res. 50 (2000) 440-447.

[11] Y. Shai, Mode of action of membrane active antimicrobial peptides. Pept. Sci. 66 (2002) 236-248.

[12] S.K. Straus, R.E. Hancock, Mode of action of the new antibiotic for Gram-positive pathogens daptomycin: comparison with cationic antimicrobial peptides and lipopeptides, (BBA)-Biomembranes 1758 (2006) 1215-1223.

[13] R.K. Sharma, R.P. Reddy, W. Tegge, R. Jain, R. Discovery of Trp-His and His-Arg analogues as new structural classes of short antimicrobial peptides. J. Med. Chem. 52 (2009), 7421-7431.

[14] A. Mahindra, N. Bagra, N. Wangoo, S.I. Khan, M. R. Jacob, R. Jain, Discovery of short peptides exhibiting high potency against Cryptococcus neoformans. ACS Med. Chem. Lett. 5 (2014), 315-320.

[15] A. Mahindra, K.K. Sharma, D. Rathore, S.I. Khan, M.R. Jacob, R. Jain, Synthesis and antimicrobial activities of His(2-aryl)-Arg and Trp-His(2-aryl) classes of dipeptidomimetics. Med. Chem. Commun. 5 (2014), 671-676.

[16] A. Mahindra, N. Bagra, N. Wangoo, R. Jain, S.I. Khan, M.R. Jacob, R. Jain, Synthetically modified L-histidine-rich peptidomimetics exhibit potent activity against Cryptococcus neoformans. Bioorg. Med. Chem. Lett. 24 (2014), 31503154. 
[17] S. Mittal, I.K. Maurya, S. Kaur, A. Swami, R. Jain, N. Wangoo, R.K. Sharma, Insights into mechanistic and synergistic aspects of novel synthetic short cationic antibacterial peptides. ChemistrySelect, 1 (2016), 5510-5516.

[18] S. Mittal, S. Kaur, A. Swami, I.K. Maurya, R. Jain, N. Wangoo, R.K. Sharma, Alkylated histidine based short cationic antifungal peptides: synthesis, biological evaluation and mechanistic investigations. RSC Adv. 6 (2016), 41951-41961.

[19] N.P. de Sa, C. I. Lino, N.C. Fonseca, B.M. Borelli, J.P. Ramos, E.M. SouzaFagundes, C.A. Rosa, D.A. Santos, R.B. de Oliveira, S. Johann, Thiazole compounds with activity against Cryptococcus gattii and Cryptococcus neoformans in vitro. Eur. J. Med. Chem. 102 (2015), 233-242.

[20] W.S. Alwan, R. Karpoormath, M.B. Palkar, H.M. Patel, R.A. Rane, M.S. Shaikh, A. Kajee, K.P. Mlisana, Novel imidazo[2,1-b]-1,3,4-thiadiazoles as promising antifungal agents against clinical isolate of Cryptococcus neoformans. Eur. J. Med. Chem. 95 (2015), 514-525.

[21] R.I. Mahato, A.S. Narang, L. Thoma, D.D. Miller, Emerging trends in oral delivery of peptide and protein drugs. Crit. Rev. Ther. Drug Carrier Syst. 20 (2003) 153214.

[22] T. Bruckdorfer, O. Marder, F. Albericio, From production of peptides in milligram amounts for research to multi-tons quantities for drugs of the future. Curr. Pharm. Biotechnol. 5 (2004) 29-43.

[23] A.S. De Groot, D.W. Scott, Immunogenicity of protein therapeutics. Trends Immunol. 28 (2007): 482-490. 
[24] B. Findlay, G.G. Zhanel, F. Schweizer, Cationic amphiphiles, a new generation of antimicrobials inspired by the natural antimicrobial peptide scaffold. Antimicrob. Agents Chemother. 54 (2010) 4049-4058.

[25] M. Xiong, M. Chen, J. Zhang, Rational Evolution of Antimicrobial Peptides Containing Unnatural Amino Acids to Combat Burn Wound Infections. Chem. Biol. Drug Des.88 (2016) 404-410.

[26] Y. Shi, P. Teng, P. Sang, F. She, L. Wei, J. Cai, $\gamma$-AApeptides: Design, Structure, and Applications. Acc. Chem. Res. 49 (2016) 428-441.

[27] V. Panduranga, G. Prabhu, R. Kumar, V.V. Sureshbabu, A facile one pot route for the synthesis of imide tethered peptidomimetics. Org. Biomol. Chem. 14 (2016) $556-563$.

[28] F. Azmi, A.G. Elliott, N. Marasini, S. Ramu, Z. Ziora, A.M. Kavanagh, M.A. Blaskovich, M.A. Cooper, M. Skwarczynski, I. Toth, Short cationic lipopeptides as effective antibacterial agents: Design, physicochemical properties and biological evaluation. Biorg. Med. Chem. 24 (2016) 2235-2241.

[29] M. Pasupuleti, A. Chalupka, M. Mörgelin, A. Schmidtchen, M. Malmsten, Tryptophan end-tagging of antimicrobial peptides for increased potency against Pseudomonas aeruginosa. (BBA)-Gen. Subjects. 1790 (2009) 800-808.

[30] S.E. Blondelle, E. PeRez-Paya, R.A. Houghten, Synthetic combinatorial libraries: novel discovery strategy for identification of antimicrobial agents, Antimicrob. Agents Chemother. 40 (1996) 1067. 
[31] C. Pinilla, J. Appel, S. Blondelle, C. Dooley, B. Dörner, J. Eichler, J. Ostresh, R.A. Houghten, A review of the utility of soluble peptide combinatorial libraries. Biopolymers. 37 (1995) 221-240.

[32] R.S. McDowell, K.A. Elias, M.S. Stanley, D.J. Burdick, J.P. Burnier, K.S. Chan, W.J. Fairbrother, R.G. Hammonds, G.S. Ingle, N.E. Jacobsen, Growth hormone secretagogues: characterization, efficacy, and minimal bioactive conformation. Proc. Natl. Acad. Sci.U S A 92 (1995) 11165-11169.

[33] A. Inui, A. Asakawa, C.Y. Bowers, G. Mantovani, A. Laviano, M.M. Meguid, M. Fujimiya, Ghrelin, appetite, and gastric motility: the emerging role of the stomach as an endocrine organ. FASEB J. 18 (2004) 439-456.

[34] T. Waseem, M. Duxbury, H. Ito, F. Rocha, D. Lautz, E. Whang, S. Ashley, M. Robinson, Ghrelin ameliorates TNF-a induced anti-proliferative and pro-apoptotic effects and promotes intestinal epithelial restitution. J. Am. Coll. Surg. 199 (2004) 16.

[35] T. Waseem, M. Duxbury, H. Ito, S.W. Ashley, M.K. Robinson, Exogenous ghrelin modulates release of pro-inflammatory and anti-inflammatory cytokines in LPSstimulated macrophages through distinct signaling pathways. Surgery. 143 (2008) $334-342$.

[36] A. Stengel, Y. Taché, Ghrelin-a pleiotropic hormone secreted from endocrine X/A-like cells of the stomach. Front. Neurosci. 6 (2012) 24.

[37] M. Lutter, I. Sakata, S. Osborne-Lawrence, S.A. Rovinsky, J.G. Anderson, S. Jung, S. Birnbaum, M. Yanagisawa, J.K. Elmquist, E.J. Nestler, The orexigenic hormone 
ghrelin defends against depressive symptoms of chronic stress. Nat. Neurosci. 11 (2008) 752-753.

[38] D. Cibrián, H. Ajamieh, J. Berlanga, O.S. León, J.S. Alba, M.J.-T. Kim, T. Marchbank, J.J. Boyle, F. Freyre, D.G. Del Barco, Use of growth-hormonereleasing peptide-6 (GHRP-6) for the prevention of multiple organ failure. Clin. Sci. 110 (2006) 563-573.

[39] C. Min, K. Ohta, M. Kajiya, T. Zhu, K. Sharma, J. Shin, H. Mawardi, M. Howait, J. Hirschfeld, L. Bahammam, The antimicrobial activity of the appetite peptide hormone ghrelin. Peptides. 36 (2012) 151-156.

[40] C. Bowers, F. Momany, G. Reynolds, A. Hong, On the in Vitro and in Vivo activity of a new synthetic hexapeptide that acts on the pituitary to specifically release growth hormone. Endocrinology. 114 (1984) 1537-1545.

[41] B. Kundu, G. Singh, G.K. Jain, A. Shukla, N. Shrivastava, G.K. Patnaik, Wound healing activity of peptides related to growth hormone releasing hexapeptide. Protein Pept. Lett. 5 (1998) 83-86.

[42] B. Kundu, S. Rastogi, S. Batra, S. Raghuwanshi, P. Shukla, Combinatorial approach to lead optimization of a novel hexapeptide with antifungal activity. Bioorg. Med. Chem. Lett. 10 (2000) 1779-1781.

[43] B. Kundu, T. Srinivasan, A. Kesarwani, A. Kavishwar, S. Raghuwanshi, S. Batra, P. Shukla, Identification of novel antifungal nonapeptides through the screening of combinatorial peptide libraries based on a hexapeptide motif. Bioorg. Med. Chem. Lett. 12 (2002) 1473-1476. 
[44] M. Kumar, A.K. Chaturvedi, A. Kavishwar, P. Shukla, A. Kesarwani, B. Kundu, Identification of a novel antifungal nonapeptide generated by combinatorial approach, Int. J. Antimicrob. Agents. 25 (2005) 313-320.

[45] R.K. Sharma, S. Sundriyal, N. Wangoo, W. Tegge, R. Jain, New antimicrobial hexapeptides: synthesis, antimicrobial activities, cytotoxicity, and mechanistic studies. Chem. Med. Chem. 5 (2010) 86-95.

[46] T. Kiyota, S. Lee, G. Sugihara, Design and synthesis of amphiphilic $\alpha$-helical model peptides with systematically varied hydrophobic-hydrophilic balance and their interaction with lipid-and bio-membranes, Biochemistry. 35 (1996) 1319613204.

[47] S.-Y. Wei, J.-M. Wu, Y.-Y. Kuo, H.-L. Chen, B.-S. Yip, S.-R. Tzeng, J.-W. Cheng, Solution structure of a novel tryptophan-rich peptide with bidirectional antimicrobial activity. J. Bacteriol. 188 (2006) 328-334.

[48] M.A. Schmitt, B. Weisblum, S.H. Gellman, Interplay among folding, sequence, and lipophilicity in the antibacterial and hemolytic activities of $\alpha / \beta$-peptides. J. Am. Chem. Soc. 129 (2007) 417-428.

[49] V.P. Torchilin, Recent advances with liposomes as pharmaceutical carriers. Nat. Rev. Drug Discov. 4 (2005) 145-160.

[50] NCCLS, Methods for Dilution Antimicrobial Susceptibility Tests for Bacteria that Grow Aerobically; Approved Standard, Seventh Edition M7-A7. National Committee on Clinical Laboratory Standards, 2006, 26(2). 
[51] NCCLS, Susceptibility Testing of Mycobacteria, Nocardia, and Other Aerobic Actinomycetes; Tentative Standard-Approved Standard, M24-A. National Committee on Clinical Laboratory Standards, 2003, 23(18).

[52] S.G. Franzblau, R.S. Witzig, J.C. McLaughlin, P. Torres, G. Madico, A. Hernandez, M.T. Degnan, M.B. Cook, V.K. Quenzer, R.M. Ferguson, Rapid, lowtechnology MIC determination with clinical Mycobacterium tuberculosis isolates by using the microplate Alamar Blue assay. J. Clin. Microbiol. 36 (1998) 362-366.

[53] NCCLS, Reference Method for Broth Dilution Antifungal Susceptibility Testing of Yeasts; Approved Standard M27-A2. National Committee on Clinical Laboratory Standards, 2002, 22 (15).

[54] E. Borenfreund, H. Babich, N. Martin-Alguacil, Rapid chemosensitivity assay with human normal and tumor cells in vitro. In Vitro Cell Dev. Biol. 26 (1990), 10301034.

[55] D. Mares, Electron microscopy of Microsporum cookei after 'in vitro' treatment with protoanemonin: A combined SEM and TEM study. Mycopathologia. 108 (1989) 37-46.

[56] M. Borgers, M. -A. Van De Ven, J. Van Cutsem, Structural degeneration of Aspergillus fumigatus after exposure to saperconazole, J. Med. Veter. Mycol. 27 (1989) 381-389. 


\section{Figure Captions}

Fig. 1. Structure of lead peptides $\mathbf{1}$ and $\mathbf{2}$ indicating the positional replacement with other amino acids resulting in the synthesis of peptides 3-38. In parentheses is the synthesized peptide number as seen in the tables 1-2.

Fig. 2. Stern-Volmer plots for the quenching of Trp-fluorescence of the peptides 3, 24, 32, 34 and 36 in the presence of acrylamide in Tris-HCl buffer (control), EYPC:cholesterol (mammalian mimicking SUVs) and EYPC:EYPG (bacterial mimicking SUVs).

Fig. 3. Trypsin stability assay depicting the RP-HPLC chromatogram of peptides $\mathbf{3}, \mathbf{3 2}$ and 36 taken at $0,2,4,8,12,18$ and $24 \mathrm{~h}$ after trypsin treatment.

Fig. 4. Surface view of the fungal biofilm cells (a) positive control, (b) upon treatment with the active peptide 36, (c) upon treatment with the active peptide 3, (d) upon treatment with the least active peptide 34 .

Fig. 5. TEM images of a) Untreated EYPC:EYPG SUVs (bacterial membrane mimics); b) EYPC: EYPG SUVs (bacterial membrane mimics) treated with 36; c) Untreated EYPC:cholesterol SUVs (mammalian membrane mimics); d) EYPC: cholesterol SUVs (mammalian membrane mimics) treated with 36. The peptide concentrations used was $0.5 \mu \mathrm{g} / \mathrm{mL}$ with $2 \%(\mathrm{w} / \mathrm{v})$ phosphotungstic acid solution being used as the negative stain.

Fig. 6. a) Untreated $C$. neoformans ultrastructure, b) Treated fungal biofilm cells with peptide the active peptide 3 , c) Treated fungal biofilm cells with peptide the least active peptide 34, d) Treated fungal biofilm cells with the active peptide $\mathbf{3 6}$. 


\begin{tabular}{|c|c|c|c|c|c|c|c|c|c|c|c|c|c|c|c|c|}
\hline \multirow{2}{*}{$\begin{array}{l}\text { Peptide } \\
\text { No. }\end{array}$} & \multirow[t]{2}{*}{ Structure } & \multicolumn{3}{|c|}{ C. albicans $(\mu \mathrm{g} / \mathrm{mL})$} & \multicolumn{3}{|c|}{ C. glabrata $(\mu \mathrm{g} / \mathrm{mL})$} & \multicolumn{3}{|c|}{ C. krusei $(\mu \mathrm{g} / \mathrm{mL})$} & \multicolumn{3}{|c|}{ A. fumigatus $(\mu \mathrm{g} / \mathrm{mL})$} & \multicolumn{3}{|c|}{ C. neoformans $(\mu \mathrm{g} / \mathrm{mL})$} \\
\hline & & $\mathrm{IC}_{50}$ & MIC & MFC & $\mathrm{IC}_{50}$ & MIC & MFC & $\mathrm{IC}_{50}$ & MIC & MFC & $\mathrm{IC}_{50}$ & MIC & MFC & $\mathrm{IC}_{50}$ & MIC & MFC \\
\hline 3 & Orn-Trp-Cha-Ile-D-Phe-His(1-Bzl)-NH & NA & - & - & NA & - & - & 7.76 & 10 & 10 & NA & - & - & 0.42 & 0.63 & 0.63 \\
\hline 4 & Orn-Phe-Cha-Ile-D-Phe-His(1-Bzl)-NH ${ }_{2}$ & NA & - & - & NA & - & - & NA & - & - & NA & - & - & 1.42 & 2.5 & 2.5 \\
\hline 5 & Orn-D-Phe-Cha-Ile-D-Phe-His(1-Bzl)-NH ${ }_{2}$ & NA & - & - & NA & - & - & NA & - & - & NA & - & - & 0.7 & 1.25 & 1.25 \\
\hline 6 & Orn-Pro-Cha-Ile-D-Phe-His(1-Bzl)-NH 2 & NA & - & - & NA & - & - & NA & - & - & NA & - & - & 1.35 & 2.5 & 2.5 \\
\hline 7 & Orn-D-Pro-Cha-Ile-D-Phe-His(1-Bzl)-NH ${ }_{2}$ & NA & - & - & NA & - & - & NA & - & - & NA & - & - & 1.44 & 2.5 & 2.5 \\
\hline 8 & Orn-Leu-Cha-Ile-D-Phe-His(1-Bzl)- $\mathrm{NH}_{2}$ & NA & - & - & NA & - & - & NA & - & - & NA & - & - & 1.66 & 2.5 & 2.5 \\
\hline 9 & Orn-D-Leu-Cha-Ile-D-Phe-His(1-Bzl)-NH ${ }_{2}$ & NA & - & - & NA & - & - & NA & - & - & NA & - & - & 0.86 & 1.25 & 1.25 \\
\hline 10 & Orn-Cha-Cha-Ile-D-Phe-His(1-Bzl)- $\mathrm{NH}_{2}$ & NA & - & - & NA & - & - & 17.11 & 20 & 20 & NA & - & - & 1.01 & 1.25 & 2.5 \\
\hline 11 & Orn-Phg-Cha-Ile-D-Phe-His(1-Bzl)-NH ${ }_{2}$ & NA & - & - & NA & - & - & NA & - & - & NA & - & - & 1.76 & 2.5 & 5 \\
\hline 12 & Orn-Nle-Cha-Ile-D-Phe-His(1-Bzl)- $\mathrm{NH}_{2}$ & NA & - & - & NA & - & - & NA & - & - & NA & - & - & 1.44 & 2.5 & 2.5 \\
\hline 13 & Orn-D-Trp-Cha-D-Ile-D-Phe-His(1-Bzl)-NH & 16.82 & 20 & 20 & NA & - & - & 6.44 & 10 & 10 & NA & - & - & 1.41 & 2.50 & 2.50 \\
\hline 14 & Orn-D-Trp-Cha-Leu-D-Phe-His(1-Bzl)- $\mathrm{NH}_{2}$ & NA & - & - & NA & - & - & 15.98 & 20 & 20 & NA & - & - & 3.29 & 5.00 & 5.00 \\
\hline 15 & Orn-D-Trp-Cha-D-Leu-D-Phe-His(1-Bzl)-NH ${ }_{2}$ & NA & - & - & NA & - & - & 19.98 & - & - & NA & - & - & 1.29 & 2.50 & 2.50 \\
\hline 16 & Orn-D-Trp-Cha-Val-D-Phe-His(1-Bzl)-NH ${ }_{2}$ & NA & - & - & NA & - & - & NA & - & - & NA & - & - & 0.62 & 1.25 & 1.25 \\
\hline 17 & Orn-D-Trp-Cha-D-Val-D-Phe-His(1-Bzl)-NH ${ }_{2}$ & 17.57 & 20 & 20 & NA & - & - & 12.98 & 20 & 20 & NA & - & - & 0.69 & 1.25 & 1.25 \\
\hline 18 & Orn-D-Trp-Cha-Bal-D-Phe-His(1-Bzl)-NH ${ }_{2}$ & 8.65 & 10 & 10 & 7.56 & 10 & 10 & 6.51 & 10 & 10 & 6.56 & 10 & 10 & 0.68 & 1.25 & 1.25 \\
\hline 19 & Orn-D-Trp-Cha-Nal-D-Phe-His(1-Bzl)-NH ${ }_{2}$ & 10.50 & 20 & 20 & 17.9 & 20 & 20 & 6.64 & 10 & 10 & 11.5 & 20 & 20 & 1.07 & 2.50 & 2.50 \\
\hline 20 & Orn-D-Trp-Cha-Cha-D-Phe-His(1-Bzl)-NH ${ }_{2}$ & 6.05 & 10 & 10 & NA & - & - & 6.53 & 10 & 10 & 17.9 & 20 & 20 & 0.70 & 1.25 & 1.25 \\
\hline 21 & Orn-D-Trp-Cha-Phg-D-Phe-His(1-Bzl)-NH & 11.79 & 20 & 20 & NA & - & - & 8.91 & 10 & 10 & NA & - & - & 0.63 & 1.25 & 2.5 \\
\hline 22 & Orn-D-Trp-Cha-Ile-Bal-His(1-Bzl)-NH ${ }_{2}$ & NA & - & - & 10.2 & 20 & 20 & 7.12 & 20 & 20 & NA & - & - & 0.91 & 1.25 & 1.25 \\
\hline 23 & Orn-D-Trp-Cha-Ile-Nal-His(1-Bzl)-NH 2 & NA & - & - & NA & - & - & 11.55 & 10 & 20 & NA & - & - & 0.56 & 1.25 & 1.25 \\
\hline 24 & Orn-D-Trp-Cha-Ile-Cha-His(1-Bzl)-NH ${ }_{2}$ & 17.40 & 20 & 20 & 11.5 & 20 & 20 & 5.76 & 10 & 20 & NA & - & - & 0.46 & 1.25 & 1.25 \\
\hline 25 & Orn-D-Trp-Cha-Ile-Ala(9-anth)-His(1-Bzl)--NH ${ }_{2}$ & 15.85 & 20 & 20 & 14.4 & 20 & 20 & 3.81 & 5 & 10 & NA & - & - & 0.53 & 1.25 & 1.25 \\
\hline 26 & Arg-D-Trp-D-Phe-Phe(4-Me)-D-Phe-His(1-Bzl)-NH & 19.6 & 20 & 20 & NA & - & - & 16.29 & 20 & 20 & NA & - & - & 1.36 & 2.5 & 2.5 \\
\hline 27 & Lys-D-Trp-D-Phe-Phe(4-Me)-D-Phe-His(1-Bzl)-NH ${ }_{2}$ & NA & - & - & NA & - & - & 13.85 & 20 & 20 & NA & - & - & 1.3 & 2.5 & 2.5 \\
\hline 28 & Dab-D-Trp-D-Phe-Phe(4-Me)-D-Phe-His(1-Bzl)--NH 2 & NA & - & - & NA & - & - & 19.0 & - & - & NA & - & - & 0.8 & 1.25 & 1.25 \\
\hline 29 & Phe(4-NH ${ }_{2}$ )-D-Trp-D-Phe-Phe(4-Me)-D-Phe-His(1-Bzl)- $\mathrm{NH}_{2}$ & NA & - & - & NA & - & - & NA & - & - & NA & - & - & 3.74 & 5.00 & 5.00 \\
\hline 30 & D-Arg-D-Trp-D-Phe-Phe(4-Me)-D-Phe-His(1-Bzl)-NH ${ }_{2}$ & NA & - & - & NA & - & - & 16 & 20 & 20 & NA & - & - & 1.04 & 2.5 & 2.5 \\
\hline 31 & Orn-D-Trp-D-Phe-Phe(4-Me)-D-Phe-His-NH ${ }_{2}$ & NA & - & - & NA & - & - & NA & - & - & NA & - & - & 0.8 & 1.25 & 1.25 \\
\hline 32 & Orn-D-Trp-D-Phe-Phe(4-Me)-D-Phe-Orn- $\mathrm{NH}_{2}$ & NA & - & - & NA & - & - & 15.49 & 20 & 20 & NA & - & - & 0.46 & 0.63 & 0.63 \\
\hline 33 & Orn-D-Trp-D-Phe-Phe(4-Me)-D-Phe-Dab-NH ${ }_{2}$ & NA & - & - & NA & - & - & 14.77 & 20 & 20 & NA & - & - & 0.8 & 1.25 & 1.25 \\
\hline 34 & Orn-D-Trp-D-Phe-Phe(4-Me)-D-Phe-Phe(4- $\left.\mathrm{NH}_{2}\right)-\mathrm{NH}_{2}$ & NA & - & - & NA & - & - & NA & - & - & NA & - & - & 4.73 & 5.00 & 5.00 \\
\hline 35 & Orn-D-Trp-D-Phe-Phe(4-Me)-D-Phe-D-His- $\mathrm{NH}_{2}$ & NA & - & - & NA & - & - & 5.16 & 10 & 10 & NA & - & - & 0.8 & 1.25 & 1.25 \\
\hline 36 & Orn-D-Trp-D-Phe-Phe(4-Me)-D-Phe-D-Lys- $\mathrm{NH}_{2}$ & NA & - & - & NA & - & - & 12.07 & 20 & 20 & NA & - & - & 0.4 & 0.63 & 0.63 \\
\hline 37 & Orn-D-Trp-D-Phe-Phe(4-Me)-D-Phe-D-Arg-NH ${ }_{2}$ & NA & - & - & NA & - & - & 13.97 & 20 & 20 & NA & - & - & 0.83 & 1.25 & 1.25 \\
\hline 38 & Orn-D-Trp-D-Phe-Phe(4-Me)-D-Phe-D-Orn- $\mathrm{NH}_{2}$ & NA & - & - & NA & - & - & 9.7 & 20 & 20 & NA & - & - & 0.67 & 1.25 & 1.25 \\
\hline
\end{tabular}

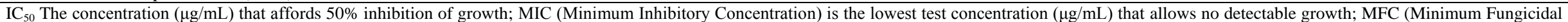

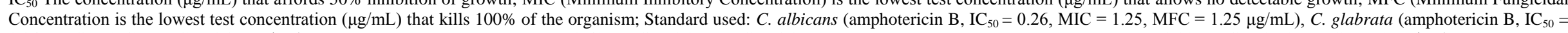

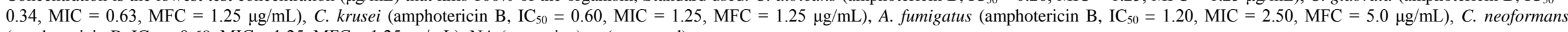
(amphotericin $\mathrm{B}, \mathrm{IC}_{50}=0.69, \mathrm{MIC}=1.25, \mathrm{MFC}=1.25 \mu \mathrm{g} / \mathrm{mL}$ ); NA (not active); - (not tested).

All peptides were evaluated for cytotoxicity in the noncancerous Vero cells. None of the peptide showed any cytotoxic effects up to the concentration of $10 \mu \mathrm{g} / \mathrm{mL}$.

Amino acid abbreviations used: Cha, cyclohexylalanine; Phg, phenylglycine; Nle, norleucine; Bal, 3-benzothienylalanine; Nal, 1-naphthylalanine; Dab, 2,4-diaminobutyric acid. 
Table 2. Antibacterial activities of peptides

\begin{tabular}{|c|c|c|c|c|c|c|c|c|c|c|c|c|c|c|c|c|}
\hline \multirow[t]{2}{*}{$\begin{array}{l}\text { Peptide } \\
\text { No. }\end{array}$} & \multirow[t]{2}{*}{ Structure } & \multicolumn{3}{|c|}{ MRSA $(\mu \mathrm{g} / \mathrm{mL})$} & \multicolumn{3}{|c|}{ S. aureus $(\mu \mathrm{g} / \mathrm{mL})$} & \multicolumn{3}{|c|}{ E. coli $(\mu \mathrm{g} / \mathrm{mL})$} & \multicolumn{3}{|c|}{ P. aeruginosa $(\mu \mathrm{g} / \mathrm{mL})$} & \multirow{2}{*}{$\begin{array}{l}\begin{array}{l}M . \\
(\mu \mathrm{g} / \mathrm{mL}\end{array} \\
\mathrm{IC}_{50}\end{array}$} & \multicolumn{2}{|c|}{ intracellulare } \\
\hline & & $\mathrm{IC}_{50}$ & MIC & MBC & $\mathrm{IC}_{50}$ & MIC & $\mathrm{MBC}$ & $\mathrm{IC}_{50}$ & MIC & MBC & $\mathrm{IC}_{50}$ & MIC & MBC & & MIC & MBC \\
\hline 3 & Orn-Trp-Cha-Ile-D-Phe-His(1-Bzl)- $\mathrm{NH}_{2}$ & $>20$ & - & - & $>20$ & - & - & 10.6 & - & - & NA & - & - & NA & - & - \\
\hline 4 & Orn-Phe-Cha-Ile-D-Phe-His(1-Bzl)- $\mathrm{NH}_{2}$ & $>20$ & - & - & $>20$ & - & - & $>20$ & - & - & NA & - & - & NA & - & - \\
\hline 5 & Orn-D-Phe-Cha-Ile-D-Phe-His(1-Bzl)-NH ${ }_{2}$ & $>20$ & - & - & $>20$ & - & - & $>20$ & - & - & NA & - & - & 18.1 & - & - \\
\hline 6 & Orn-Pro-Cha-Ile-D-Phe-His(1-Bzl)-NH ${ }_{2}$ & $>20$ & - & - & $>20$ & - & - & $>20$ & - & - & NA & - & - & NA & - & - \\
\hline 7 & Orn-D-Pro-Cha-Ile-D-Phe-His(1-Bzl)-NH ${ }_{2}$ & $>20$ & - & - & $>20$ & - & - & $>20$ & - & - & NA & - & - & NA & - & - \\
\hline 8 & Orn-Leu-Cha-Ile-D-Phe-His(1-Bzl)- $-\mathrm{NH}_{2}$ & $>20$ & - & - & $>20$ & - & - & $>20$ & - & - & NA & - & - & NA & - & - \\
\hline 9 & Orn-D-Leu-Cha-Ile-D-Phe-His(1-Bzl)-NH ${ }_{2}$ & $>20$ & - & - & $>20$ & - & - & $>20$ & - & - & NA & - & - & 12.3 & 20 & 20 \\
\hline 10 & Orn-Cha-Cha-Ile-D-Phe-His(1-Bzl)- $\mathrm{NH}_{2}$ & $>20$ & - & - & 15.5 & - & - & 9 & 20 & 20 & NA & - & - & NA & - & - \\
\hline 11 & Orn-Phg-Cha-Ile-D-Phe-His(1-Bzl)- $\mathrm{NH}_{2}$ & $>20$ & - & - & $>20$ & - & - & $>20$ & - & - & NA & - & - & NA & - & - \\
\hline 12 & Orn-Nle-Cha-Ile-D-Phe-His(1-Bzl)-NH & $>20$ & - & - & $>20$ & - & - & $>20$ & - & - & NA & - & - & NA & - & - \\
\hline 13 & Orn-D-Trp-Cha-D-Ile-D-Phe-His(1-Bzl)-NH ${ }_{2}$ & 18 & - & - & 7.4 & 20 & 20 & 12.7 & 20 & 20 & NA & - & - & 14.5 & 20 & 20 \\
\hline 14 & Orn-D-Trp-Cha-Leu-D-Phe-His(1-Bzl)-NH & 18.6 & - & - & 11.3 & 20 & 20 & NA & - & - & NA & - & - & 12.8 & 20 & 20 \\
\hline 15 & Orn-D-Trp-Cha-D-Leu-D-Phe-His(1-Bzl)-NH & 17.9 & - & - & 11.4 & 20 & 20 & NA & - & - & NA & - & - & 19.1 & - & - \\
\hline 16 & Orn-D-Trp-Cha-Val-D-Phe-His(1-Bzl)-NH ${ }_{2}$ & $>20$ & - & - & 18.7 & - & - & NA & - & - & NA & - & - & 17.3 & - & - \\
\hline 17 & Orn-D-Trp-Cha-D-Val-D-Phe-His(1-Bzl)-NH & $>20$ & - & - & 17.9 & - & - & NA & - & - & NA & - & - & 15.3 & 20 & 20 \\
\hline 18 & Orn-D-Trp-Cha-Bal-D-Phe-His(1-Bzl)-NH ${ }_{2}$ & 3.2 & 10 & 20 & 2.4 & 5 & 10 & 12.2 & 20 & 20 & 15.9 & - & - & NA & - & - \\
\hline 19 & Orn-D-Trp-Cha-Nal-D-Phe-His(1-Bzl)-NH $\mathrm{NH}_{2}$ & 5.8 & 10 & 20 & 2.63 & 10 & 10 & 16 & - & - & NA & - & - & NA & - & - \\
\hline 20 & Orn-D-Trp-Cha-Cha-D-Phe-His(1-Bzl)-NH ${ }_{2}$ & 5.9 & 10 & 20 & 3.6 & 10 & 20 & 10 & 20 & 20 & NA & - & - & 19.3 & - & - \\
\hline 21 & Orn-D-Trp-Cha-Phg-D-Phe-His(1-Bzl)-NH & 6.6 & 20 & 20 & 6.5 & 20 & 20 & 18.9 & - & - & NA & - & - & 7.8 & 10 & 10 \\
\hline 22 & Orn-D-Trp-Cha-Ile-Bal-His(1-Bzl)-NH ${ }_{2}$ & $>20$ & - & - & 20 & - & - & NA & - & - & NA & - & - & NA & - & - \\
\hline 23 & Orn-D-Trp-Cha-Ile-Nal-His(1-Bzl)-NH ${ }_{2}$ & 5 & 10 & 10 & 5.9 & 20 & 20 & NA & - & - & NA & - & - & NA & - & - \\
\hline 24 & 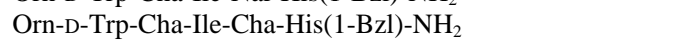 & 17.6 & - & - & 17.5 & - & - & NA & - & - & NA & - & - & NA & - & - \\
\hline 25 & Orn-D-Trp-Cha-Ile-Ala(9-anth)-His(1-Bzl)- $\mathrm{NH}_{2}$ & 5.8 & 10 & 10 & 1.6 & 5 & 10 & NA & - & - & NA & - & - & NA & - & - \\
\hline 26 & Arg-D-Trp-D-Phe-Phe(4-Me)-D-Phe-His(1-Bzl)- $\mathrm{NH}_{2}$ & 3.2 & 20 & 20 & 2.1 & 5 & 20 & 6 & 10 & 20 & NA & - & - & 6.5 & 10 & 10 \\
\hline 27 & Lys-D-Trp-D-Phe-Phe(4-Me)-D-Phe-His(1-Bzl)-NH $\mathrm{NH}_{2}$ & 9.6 & 20 & 20 & 9.1 & 20 & 20 & 11.5 & 20 & 20 & NA & - & - & 11.9 & 20 & 20 \\
\hline 28 & Dab-D-Trp-D-Phe-Phe(4-Me)-D-Phe-His(1-Bzl)--NH 2 & 10.4 & 20 & 20 & 11.7 & 20 & 20 & NA & - & - & NA & - & - & NA & - & - \\
\hline 29 & Phe(4-NH ${ }_{2}$ )-D-Trp-D-Phe-Phe(4-Me)-D-Phe-His(1-Bzl)- $\mathrm{NH}_{2}$ & NA & - & - & 10.6 & 20 & 20 & NA & - & - & NA & - & - & NA & - & - \\
\hline 30 & D-Arg-D-Trp-D-Phe-Phe(4-Me)-D-Phe-His(1-Bzl)- $\mathrm{NH}_{2}$ & 7.5 & 20 & 20 & 6.0 & 20 & 20 & 9.9 & 20 & 20 & NA & - & - & NA & - & - \\
\hline 31 & Orn-D-Trp-D-Phe-Phe(4-Me)-D-Phe-His-NH ${ }_{2}$ & NA & - & - & NA & - & - & NA & - & - & NA & - & - & NA & - & - \\
\hline 32 & Orn-D-Trp-D-Phe-Phe(4-Me)-D-Phe-Orn- $\mathrm{NH}_{2}$ & NA & - & - & NA & - & - & 16.5 & - & - & NA & - & - & NA & - & - \\
\hline 33 & Orn-D-Trp-D-Phe-Phe(4-Me)-D-Phe-Dab-NH ${ }_{2}$ & $>20$ & - & - & 16.1 & - & - & 6 & - & - & NA & - & - & NA & - & - \\
\hline 34 & Orn-D-Trp-D-Phe-Phe(4-Me)-D-Phe-Phe(4- $\left.\mathrm{NH}_{2}\right)-\mathrm{NH}_{2}$ & $>20$ & - & - & $>20$ & - & - & 19.5 & - & - & NA & - & - & NA & - & - \\
\hline 35 & Orn-D-Trp-D-Phe-Phe(4-Me)-D-Phe-D-His- $\mathrm{NH}_{2}$ & $>20$ & - & - & 18 & - & - & 12.7 & - & - & NA & - & - & NA & - & - \\
\hline 36 & Orn-D-Trp-D-Phe-Phe(4-Me)-D-Phe-D-Lys-NH ${ }_{2}$ & $>20$ & - & - & $>20$ & - & - & 8.2 & 20 & 20 & 20 & - & - & NA & - & - \\
\hline 37 & Orn-D-Trp-D-Phe-Phe(4-Me)-D-Phe-D-Arg-NH ${ }_{2}$ & $>20$ & - & - & 13.5 & 20 & 20 & 4.8 & 10 & 20 & 15.7 & - & - & NA & - & - \\
\hline 38 & Orn-D-Trp-D-Phe-Phe(4-Me)-D-Phe-D-Orn- $\mathrm{NH}_{2}$ & $>20$ & - & - & $>20$ & - & - & $>20$ & - & - & NA & - & - & NA & - & - \\
\hline
\end{tabular}

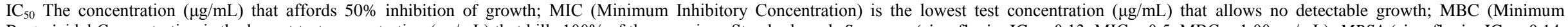

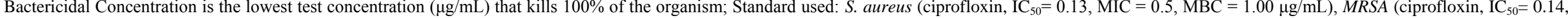

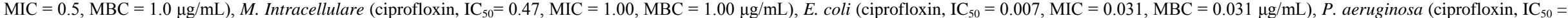
$0.09, \mathrm{MIC}=0.50, \mathrm{MBC}=1.00 \mu \mathrm{g} / \mathrm{mL}$ ); NA (not active); - (not tested).

Amino acid abbreviations used: Cha, cyclohexylalanine; Phg, phenylglycine; Nle, norleucine; Bal, 3-benzothienylalanine; Nal, 1-naphthylalanine; Dab, 2,4-diaminobutyric acid. 


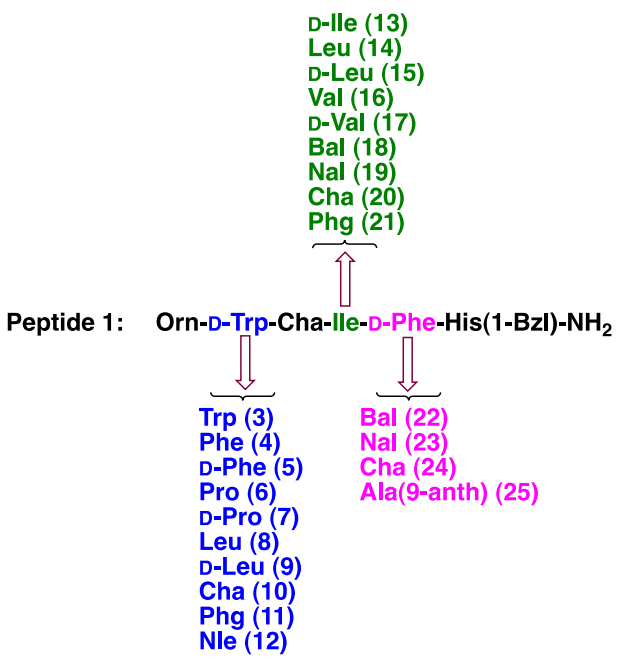

Peptide 2: Orn-D-Trp-D-Phe-Phe(4-Me)-D-Phe-His(1-Bzl)- $\mathrm{NH}_{2}$
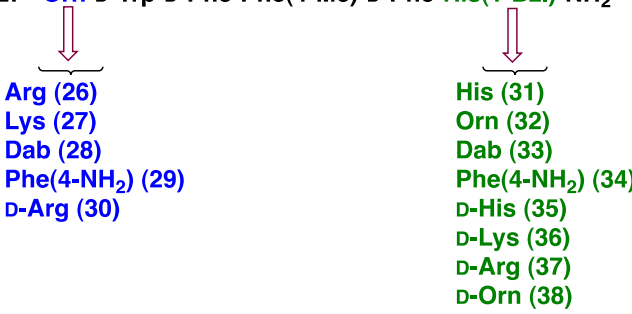

Fig. 1. 


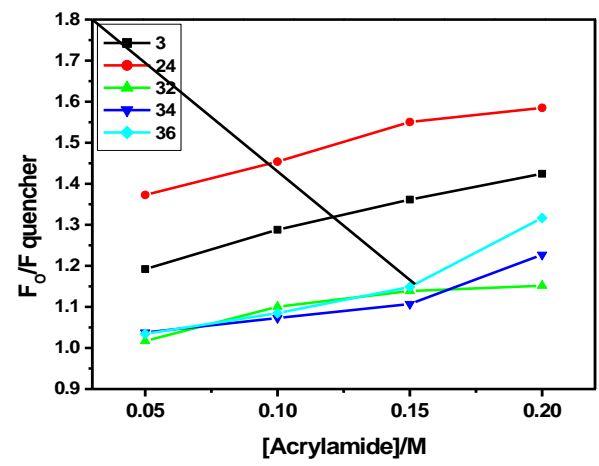

Tris-HCl

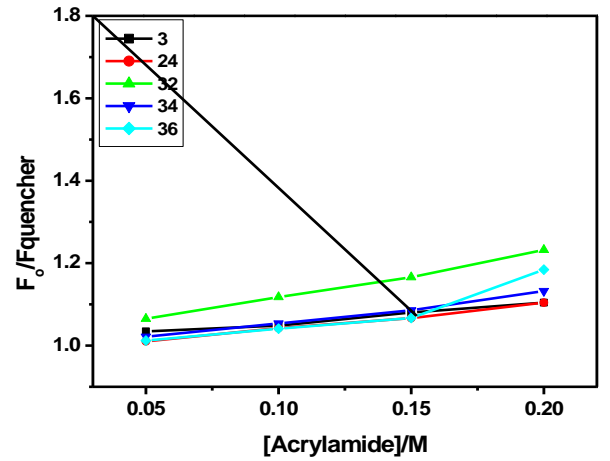

\section{EYPC:Cholesterol (10:1)}

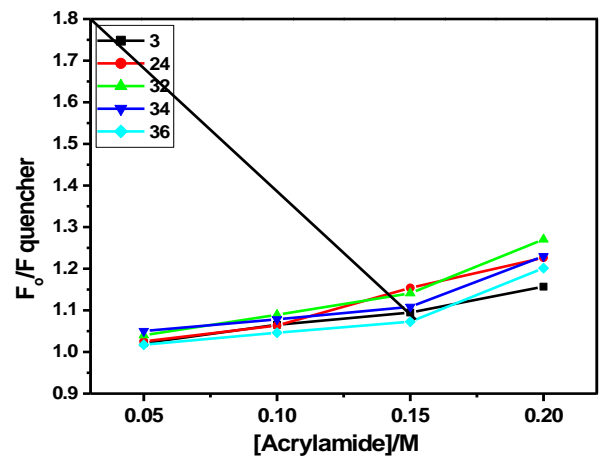

EYPC:EYPG (7:3)

Fig. 2. 

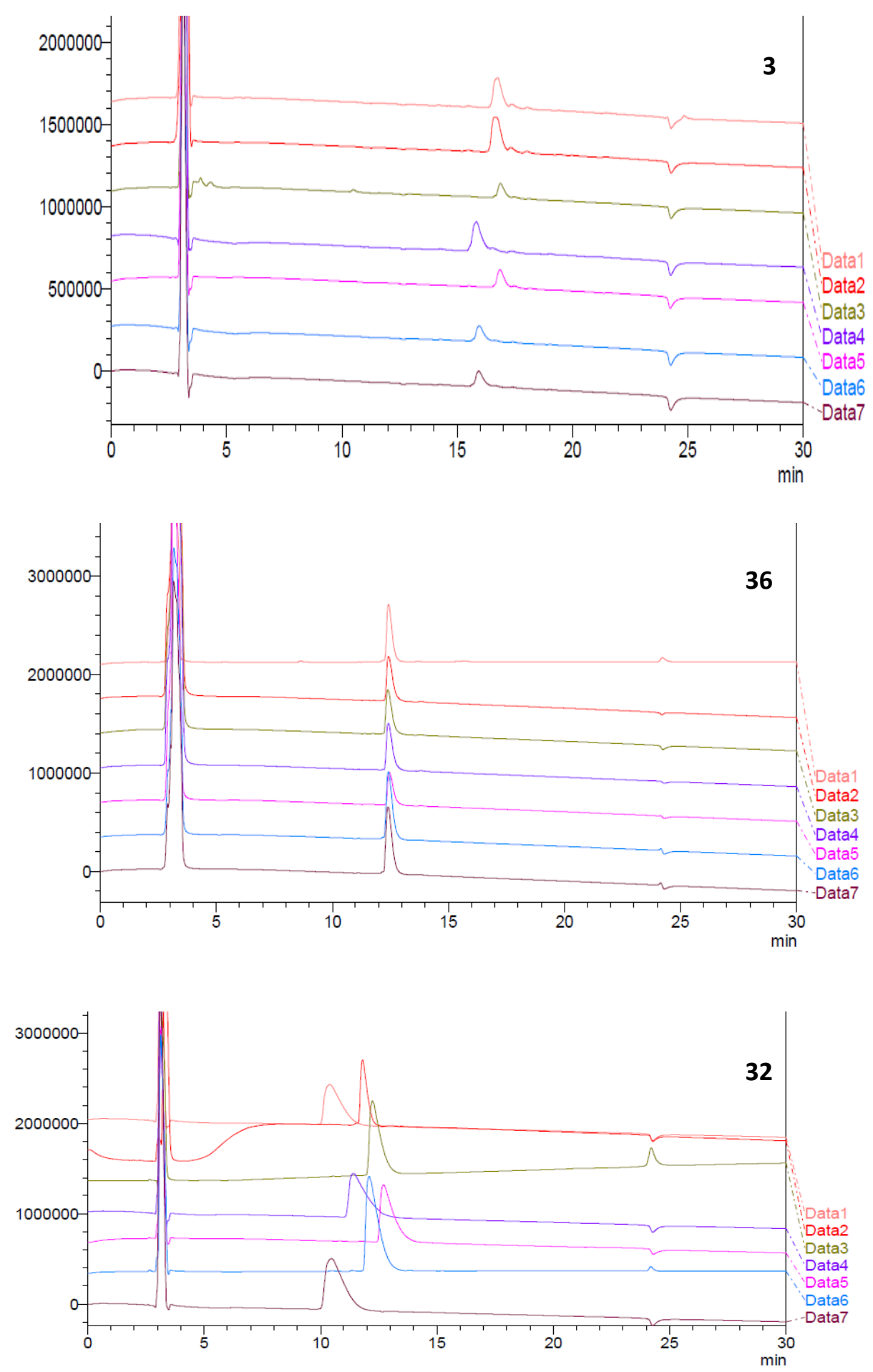

Fig. 3. 
a

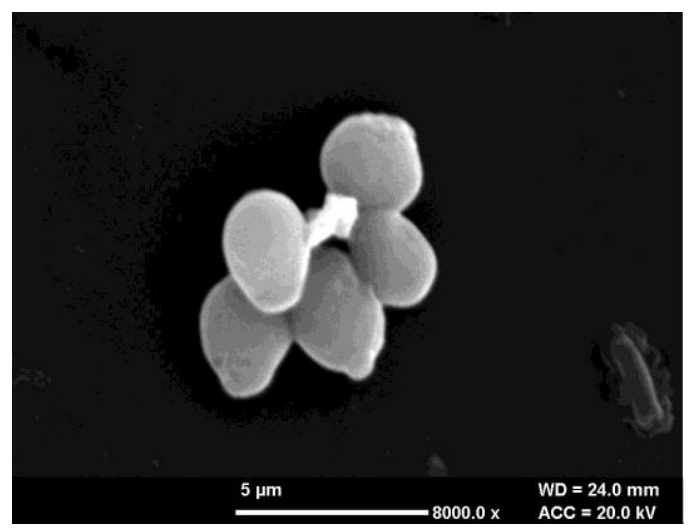

b

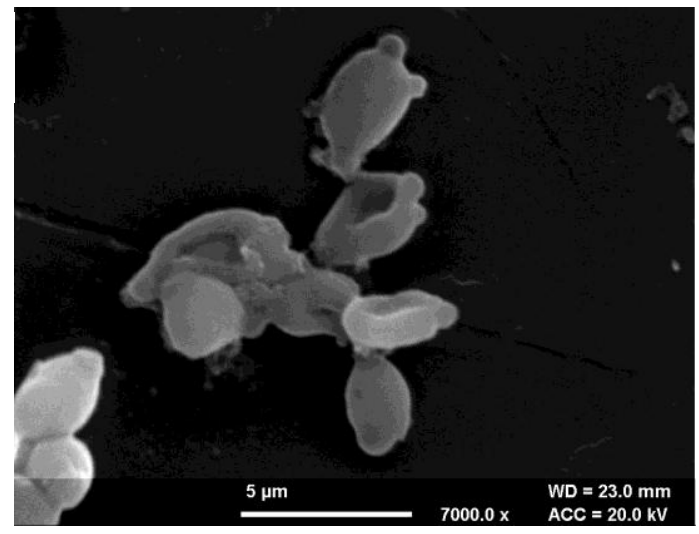

C

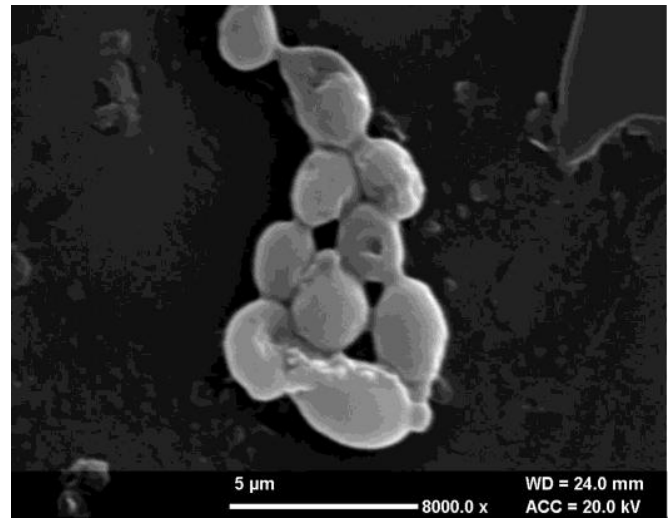

d

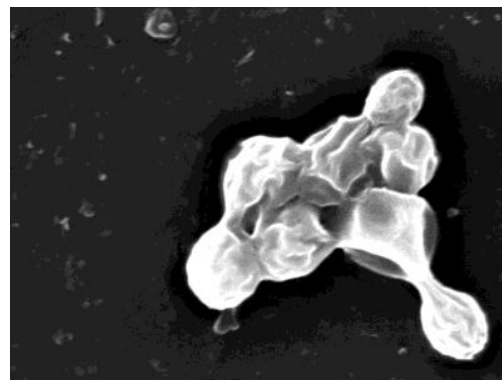

fSOW $\overline{10} 41$ 0日2: $+x$

UXֻอ - ae81
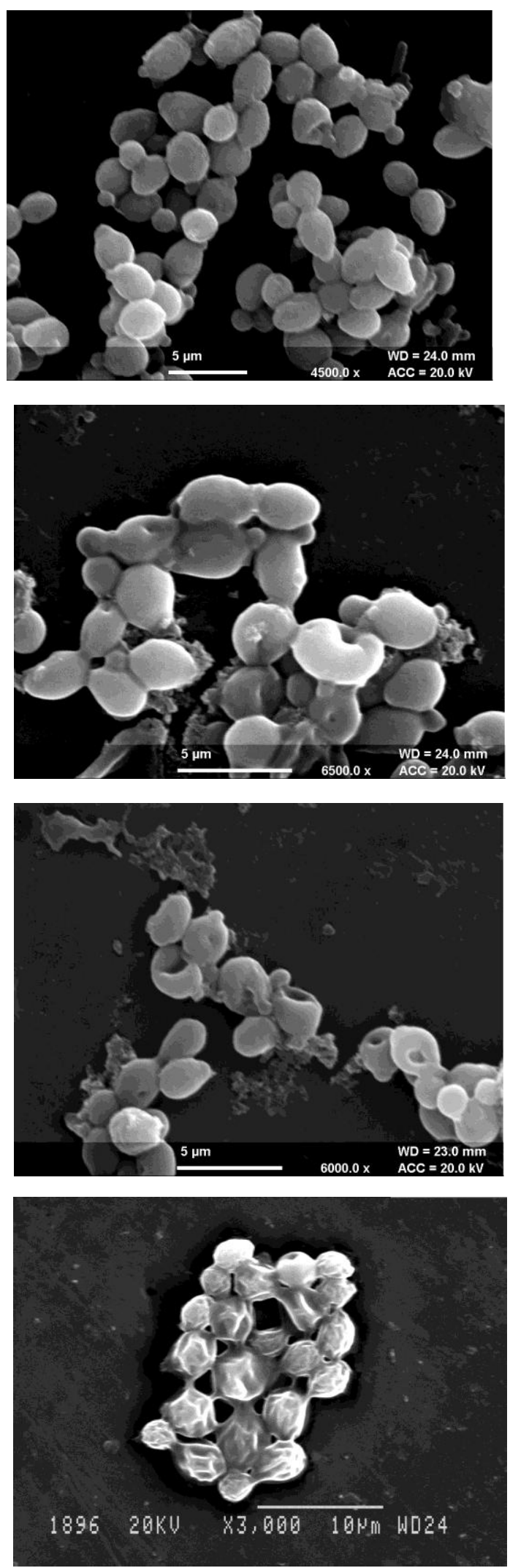

Fig. 4. 

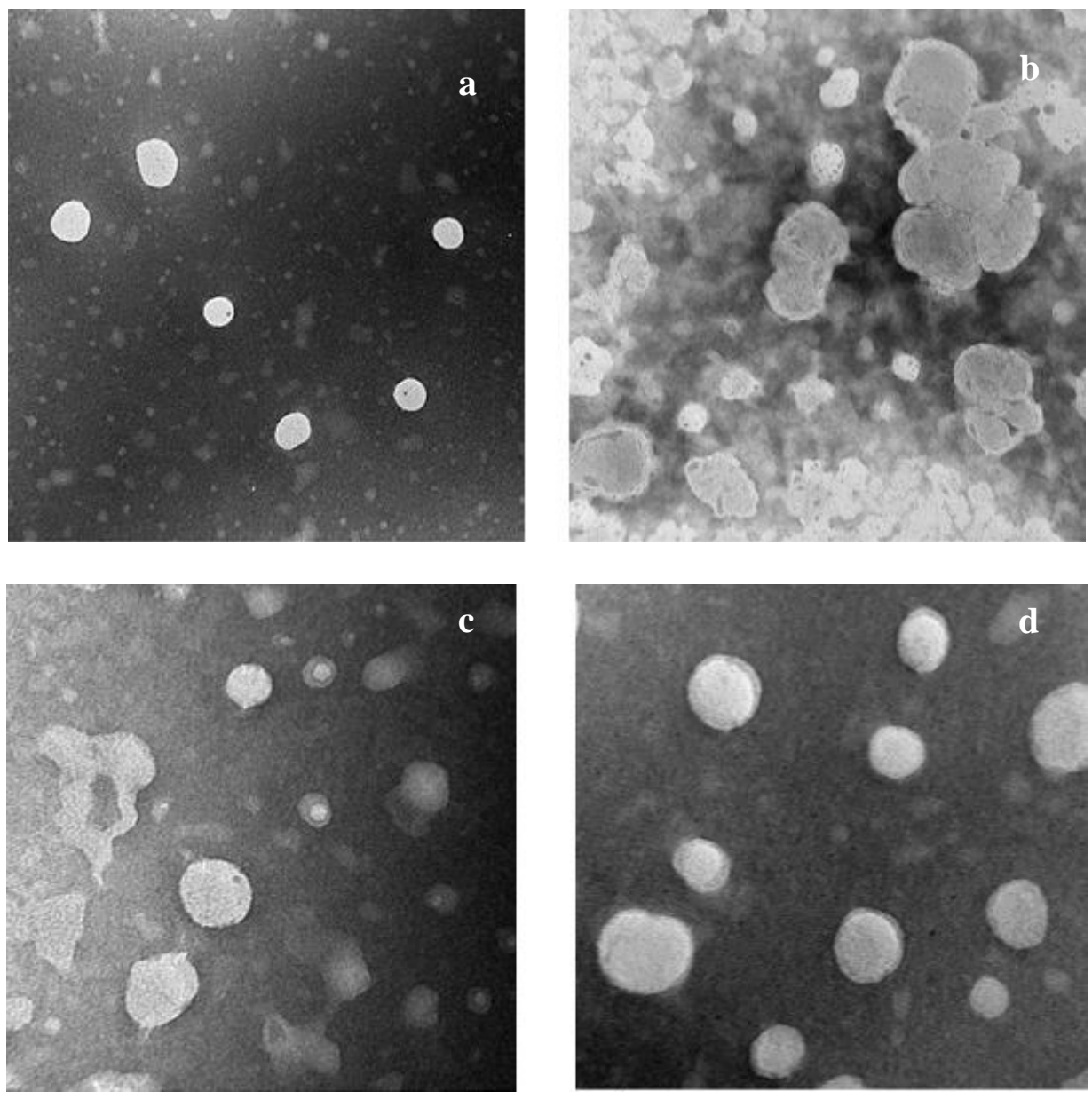

Fig. 5. 

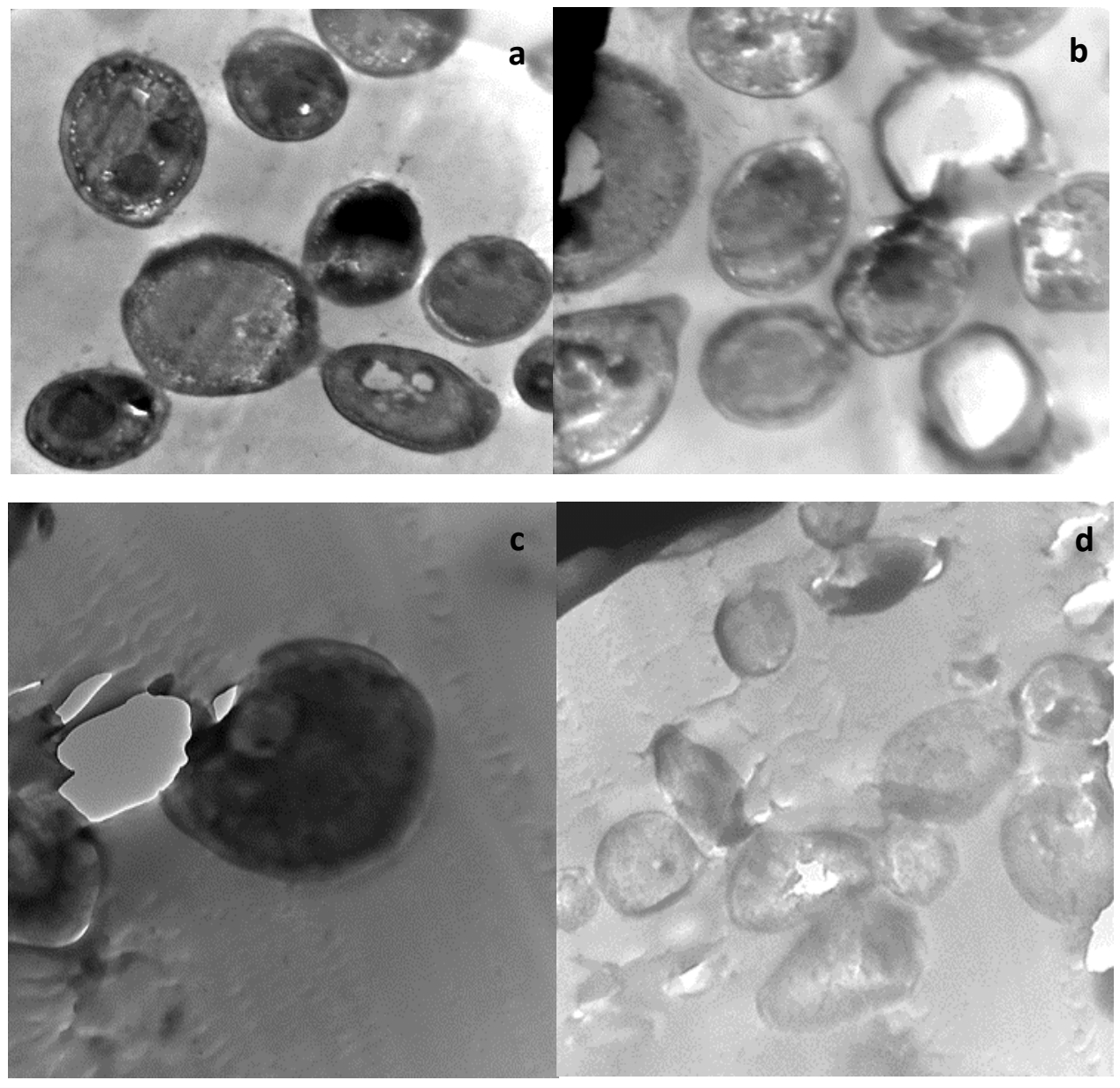

Fig. 6. 


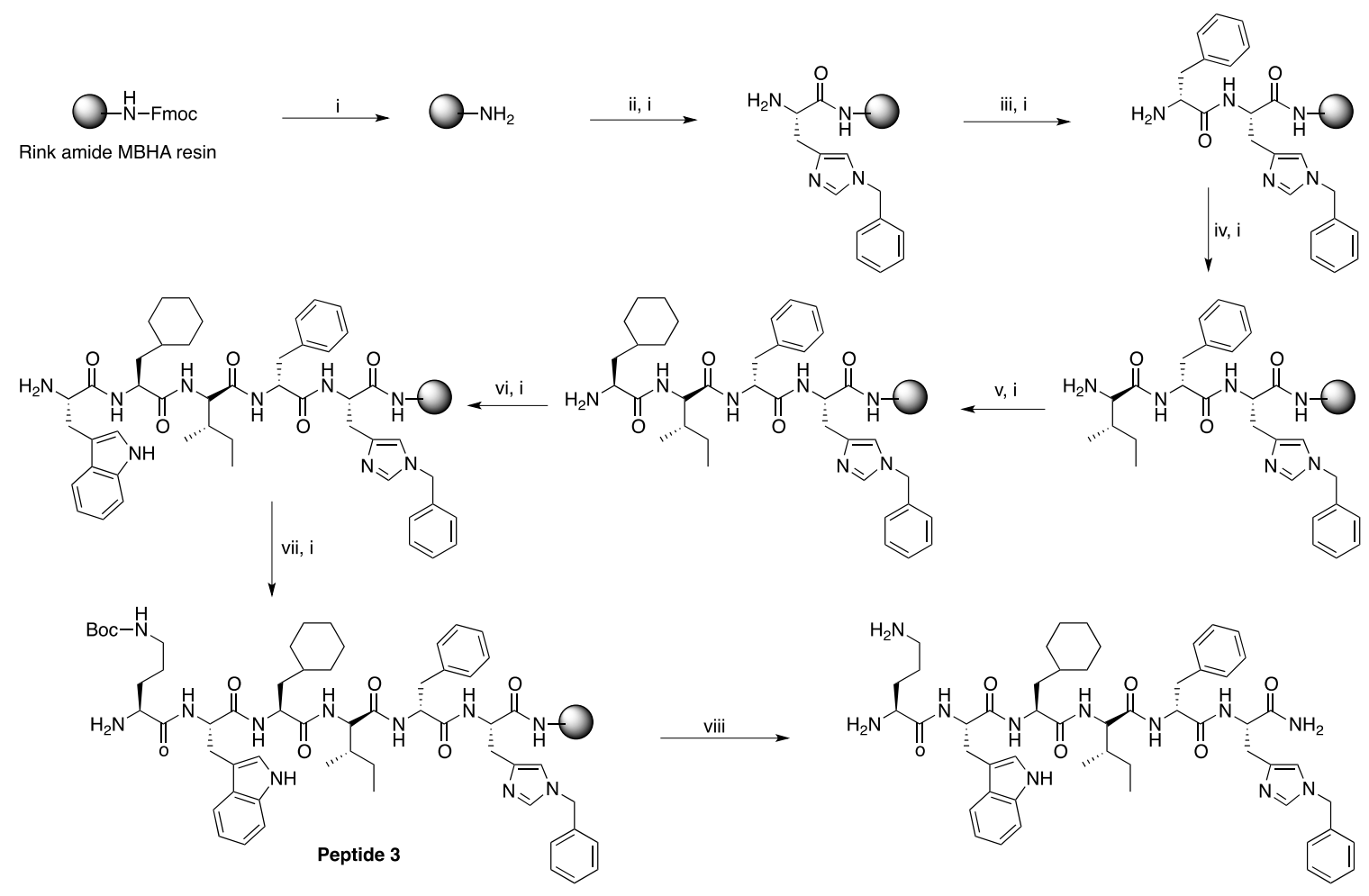

Scheme 1. Reagents and conditions: (i) $20 \%$ piperdine in DMF, 15 min; (ii) Fmoc-His(1-Bzl)-OH, TBTU, DIEA, DMF, 3h; (iii) Fmoc-D-Phe-OH, TBTU, DIEA, DMF, 3h; (iv) Fmoc-lle-OH, TBTU, DIEA, DMF, 3h; (v) Fmoc-Cha-OH, TBTU, DIEA, DMF, 3h; (vi) Fmoc-Trp-OH, TBTU, DIEA, DMF, 3h; (vii) Fmoc-Orn(Boc)$\mathrm{OH}$, TBTU, DIEA, DMF, 3h; (viii) TFA:triisopropylsilane: $\mathrm{H}_{2} \mathrm{O}$ (95:2.5:2.5), 3h. 


\section{Graphical Abstract}

Synthesis, stability and mechanistic studies of potent anticryptococcal hexapeptides

Kitika Shenmar, Krishna K. Sharma, Nishima Wangoo, Indresh K. Maurya, Vinod Kumar, Shabana I. Khan, Melissa R. Jacob, Kulbhushan Tikoo and Rahul Jain*

A series of hexapeptides containing non-proteiogenic amino acids that exhibit potent inhibition of $C$. neoformans is reported.

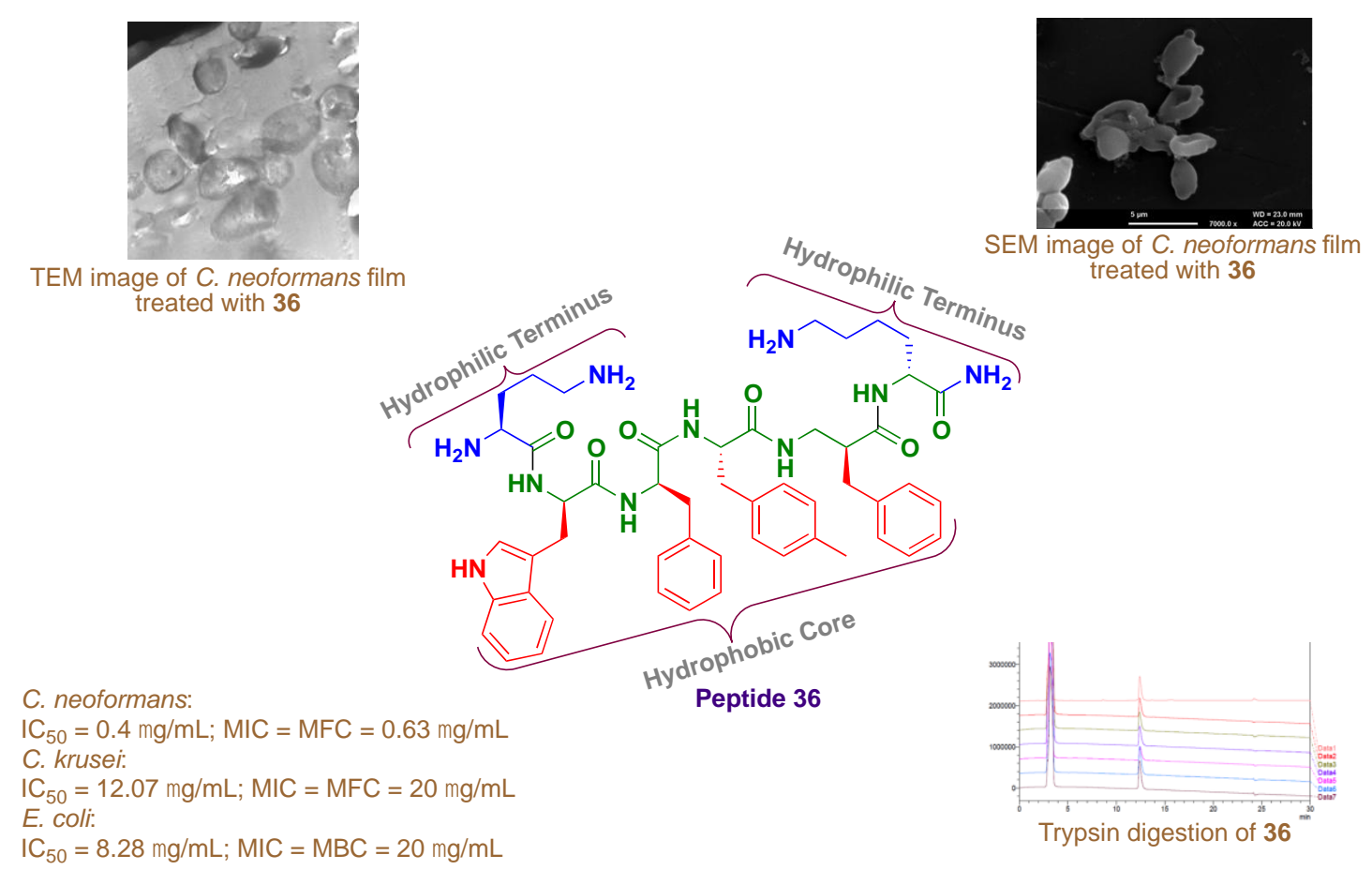

